\title{
Heavy-Mineral Dispersal and Deposition in Sandy Deltas of Glacial Lake Quinebaug, Connecticut
}

\section{U.S. GEOLOGICAL SURVEY BULLETIN 1874}

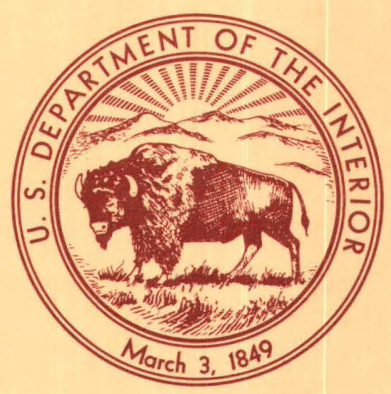




\section{AVAILABILITY OF BOOKS AND MAPS OF THE U.S. GEOLOGICAL SURVEY}

Instructions on ordering publications of the U.S. Geological Survey, along with prices of the last offerings, are given in the current-year issues of the monthly catalog "New Publications of the U.S. Geological Survey." Prices of available U.S. Geological Survey publications released prior to the current year are listed in the most recent annual "Price and Availability List." Publications that are listed in various U.S. Geological Survey catalogs (see back inside cover) but not listed in the most recent annual "Price and Availability List" are no longer available.

Prices of reports released to the open files are given in the listing "U.S. Geological Survey Open-File Reports," updated monthly, which is for sale in microfiche from the U.S. Geological Survey, Books and Open-File Reports Section, Federal Center, Box 25425, Denver, CO 80225. Reports released through the NTIS may be obtained by writing to the National Technical Information Service, U.S. Department of Commerce, Springfield, VA 22161; please include NTIS report number with inquiry.

Order U.S. Geological Survey publications by mail or over the counter from the offices given below.

\section{BY MAIL}

\section{Books}

Professional Papers, Bulletins, Water-Supply Papers, Techniques of Water-Resources Investigations, Circulars, publications of general interest (such as leaflets, pamphlets, booklets), single copies of Earthquakes \& Volcanoes, Preliminary Determination of Epicenters, and some miscellaneous reports, including some of the foregoing series that have gone out of print at the Superintendent of Documents, are obtainable by mail from

\section{U.S. Geological Survey, Books and Open-File Reports Federal Center, Box 25425 \\ Denver, CO 80225}

Subscriptions to periodicals (Earthquakes \& Volcanoes and Preliminary Determination of Epicenters) can be obtained ONLY from the

\section{Superintendent of Documents \\ Government Printing Office \\ Washington, D.C. 20402}

(Check or money order must be payable to Superintendent of Documents.)

\section{Maps}

For maps, address mail orders to

\section{U.S. Geological Survey, Map Distribution \\ Federal Center, Box 25286 \\ Denver, CO 80225}

Residents of Alaska may order maps from
Alaska Distribution Section, U.S. Geological Survey, New Federal Building - Box 12 101 Twelfth Ave., Fairbanks, AK 99701

\section{OVER THE COUNTER}

\section{Books}

Books of the U.S. Geological Survey are available over the counter at the following Geological Survey Public Inquiries Offices, all of which are authorized agents of the Superintendent of Documents:

- WASHINGTON, D.C.--Main Interior Bldg., 2600 corridor, 18 th and C Sts., NW.

- DENVER, Colorado--Federal Bldg., Rm. 169, 1961 Stout St.

- LOS ANGELES, California--Federal Bldg., Rm. 7638, 300 N. Los Angeles St.

- MENLO PARK, California--Bldg. 3 (Stop 533), Rm. 3128, 345 Middlefield Rd.

- RESTON, Virginia--503 National Center, Rm. 1C402, 12201 Sunrise Valley Dr.

- SALT LAKE CITY, Utah--Federal Bldg., Rm. 8105, 125 South State St.

- SAN FRANCISCO, California--Customhouse, Rm. 504, 555 Battery St.

- SPOKANE, Washington--U.S. Courthouse, Rm. 678, West 920 Riverside Ave..

- ANCHORAGE, Alaska--Rm. 101, 4230 University Dr.

- ANCHORAGE, Alaska--Federal Bldg, Rm. E-146, 701 C St.

\section{Maps}

Maps may be purchased over the counter at the U.S. Geological Survey offices where books are sold (all addresses in above list) and at the following Geological Survey offices:

- ROLLA, Missouri--1400 Independence Rd.

- DENVER, Colorado--Map Distribution, Bldg. 810, Federal Center

- FAIRBANKS, Alaska--New Federal Bldg., 101 Twelfth Ave. 


\section{Heavy-Mineral Dispersal and Deposition in Sandy Deltas of Glacial Lake Quinebaug, Connecticut}

By ERIC R. FORCE and BYRON D. STONE

Two deltas in the lake had similar depositional parameters but separate source terranes. Interaction between source and depositional factors determined the mineralogy of each foreset bed 


\section{DEPARTMENT OF THE INTERIOR \\ MANUEL LUJAN, Jr., Secretary \\ U.S. GEOLOGICAL SURVEY \\ Dallas L. Peck, Director}

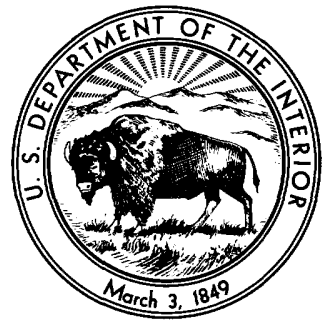

For sale by the

Books and Open-File Reports Section

U.S. Geological Survey

Federal Center, Box 25425

Denver, CO 80225

Library of Congress Cataloging in Publication Data

Force, Eric R.

Heavy-mineral dispersal and deposition in sandy deltas of glacial Lake Quinebaug, Connecticut.

(U.S. Geological Survey bulletin ; 1874)

Bibliography: $p$.

Supt. of Docs. no.: I 19.3:1874

1. Heavy minerals-Connecticut-Quinebaug, Lake. 2. Lake sedimentationConnecticut-Quinebaug, Lake. 3. Geology, Stratigraphic-Pleistocene.

I. Stone, Byron D. II. Title. III. Series: Geological Survey bulletin ; 1874.

QE75.B9 no. $1874 \quad 557.3$ s [549.9746'45] 88-600492

[QE364.2.H4] 


\title{
CONTENTS
}

\author{
Abstract 1 \\ Introduction 1 \\ Ice-Marginal Glaciolacustrine Deltas 2 \\ Study Area $\mathbf{5}$ \\ Bedrock Geology 5 \\ Glacial Deposits 5 \\ Methods of This Study 7 \\ Stratigraphic Sections 8 \\ Kitt Brook Delta 8 \\ Packerville Delta 10 \\ General Comparison of Textures and Bedding $\mathbf{1 1}$ \\ Heavy-Mineral Distribution $\mathbf{1 1}$ \\ General Character of Heavy-Mineral Grains 11 \\ Heavy-Mineral Assemblages and Sediment Sources 11 \\ Heavy-Mineral Distribution Within the Deltas 12 \\ Influence of Grain Size 13 \\ Factors Controlling the Heavy Mineralogy of Each Bed 13 \\ Grain-Size Distributions of Heavy Minerals Supplied to Each Delta 14 \\ Sorting by Shape and Density Within Each Bed 15 \\ Factor Interrelation and Consequent Predictive Capacity 17 \\ Mode of Heavy-Mineral Deposition 18 \\ Ice-Marginal Supply and Dispersal System 19 \\ Acknowledgments 20 \\ References $\mathbf{2 0}$
}

\section{FIGURES}

1. Photograph showing the topset-foreset disconformity and sets of foreset beds separated by disconformities of a typical glaciolacustrine delta in the study area $\mathbf{2}$

2. Map showing the bedrock geology, metamorphic isograds, and glacial Lake Quinebaug and its deltas $\mathbf{3}$

3. Stratigraphic columns showing sedimentary features, grain size of primary mode, and heavy-mineral contents 4

4. Grain-size histograms for light and heavy minerals of six beds 9

5-9. Graphs showing:

5. Heavy-mineral content as a function of grain size $\mathbf{1 2}$

6. Heavy-mineral percentage versus gravel percentage at Kitt Brook $\mathbf{1 3}$

7. Variation of mineral abundance and median grain size $\mathbf{1 4}$

8. Concentration of heavy-mineral species in grain-size fractions of channel samples in the Kitt Brook and Packerville deltas $\mathbf{1 6}$

9. Mineral density versus the difference between median mineral grain size and median sample grain size $\mathbf{1 7}$ 
10. Grain-size distribution histograms and mineral cumulative curves for sample K12 18

11. Graph showing the relation of size distributions of supplied debris and of any given sample and its contained minerals $\mathbf{1 9}$

12. Map showing ice-marginal supply and dispersal directions in the study area $\mathbf{2 0}$

\section{TABLES}

1. Rock-type comparisons of bedrock and gravel samples, glacial Lake Quinebaug 6

2. Relative abundance of heavy minerals in bedrock terranes, tills, and delta channel samples, Kitt Brook and Packerville deltas 7

3. Mineral percentages by weight in some heavy-mineral concentrates of the most completely analyzed samples, Kitt Brook and Packerville deltas 8

4. Average arithmetic difference between median grain sizes of whole samples and of individual constituent minerals, Kitt Brook and Packerville deltas

15 


\title{
Heavy-Mineral Dispersal and Deposition in Sandy Deltas of Glacial Lake Quinebaug, Connecticut
}

\author{
By Eric R. Force and Byron D. Stone
}

\section{Abstract}

Heavy minerals in sandy foreset beds were studied in two Pleistocene glaciolacustrine deltas. The deltas were built at about the same time into different sides of glacial Lake Quinebaug and rest on different bedrock terranes. Our aims were to determine a dispersal pattern for the heavy minerals and the mode of their deposition.

The dipping foreset beds form sets bounded by erosion surfaces and consist largely of moderately wellsorted sands and subordinate bimodal gravelly sands. Sedimentary structures show deposition by suspension, traction currents, and subordinate avalanching, probably from continuous dense turbulent underflows.

The heavy-mineral assemblages of the two deltas are quite distinct, and each is closely related to the mineralogy of the underlying bedrock terrane. Apparently little mixing of debris from different sources occurred anywhere in the dispersal system. Despite heavy-mineral contents averaging more than 5 percent and reaching almost 20 percent, heavy-mineral content of the delta sands is no greater than that of the source rocks.

Several factors appear to have no influence on heavy-mineral distribution within foreset beds: (1) there are no trends of heavy-mineral content with stratigraphic position within foreset sequences; (2) there is no orderly relation between sorting and heavy-mineral content, except in gravelly bimodal deposits; and (3) there is no relation between sedimentary structures and heavymineral content.

The only variable correlating well with heavy-mineral percentage and mineral assemblage within a delta is grain size of the host bed. In each delta, a particular modal grain size is associated with a heavy-mineral maximum. Grainsize variation also controls the concentration of individual heavy-mineral species; each species shows a maximum concentration at a particular grain size. Within a delta, concentration of a given heavy mineral was found to vary in coarse versus fine beds by as much as an order of magnitude.

In this depositional environment, heavy minerals were deposited as would be predicted from suspension equivalence. The heavy-mineral fraction is finer than the

Manuscript approved for publication October 25, 1988. bulk sample. Each heavy-mineral species forms a wellsorted population that is always in the same position relative to the size distribution of the whole sample and relative to other heavy-mineral species. The calculated sorting coefficient of any whole sample is increased by its mixed-density population.

The interaction of two factors determines the mineralogy of each bed; the first is the size distribution of supply for each mineral, and the second is the grain size of the bed. The debris of each source terrane has a characteristic proportion of minerals, each having a characteristic size distribution. Each foreset bed can draw only on this population. The size distribution of each bed implies a suspension-equivalent size in demand for each heavymineral species. Where this optimal size for a mineral matches a size interval of abundant supply, a concentration of that mineral species forms. Where that mineral dominates supply or where size of supply and demand match simultaneously for several minerals, high total heavy-mineral contents result.

\section{INTRODUCTION}

Glaciolacustrine deltas of late Pleistocene age, characterized by thick sets of steeply dipping sandy foreset beds, are the dominant type of ice-marginal deposit in the northeastern United States. This is a region of moderate relief where numerous, relatively shallow glacial lakes were impounded in front of retreating ice margins of the Laurentide ice sheet (Schafer and Hartshorn, 1965; Stewart and MacClintock, 1970; Koteff and Pessl, 1981; Stone and Peper, 1982; Stone and Borns, 1986). The preserved morphology of the deltas and the distribution of related lacustrine facies, shorelines, and lake spillways permit detailed reconstructions of basin morphometry and descriptions of specific depositional environments. Detailed regional studies (for example, Stone and Randall, 1978; Stone and Peper, 1982) clearly show that the bulk of glacially produced sand of late Wisconsinan age was deposited in subaqueous deltaic foreset and related environments.

The variety of sedimentary features in glacial deltas has received considerable study (Jopling and Walker, 1968; 
Aario, 1971; Stone, 1974; Gustavson and others, 1975; Shaw, 1975; Cohen, 1979, 1983; Serrat and others, 1983; Smith and Ashley, 1985). However, few studies have addressed the sedimentology of the entire delta system, and none has included thorough considerations of sediment source or an integrated concept of the sediment distribution systems that operated within these sandy deltas.

The mineralogy of glaciolacustrine sands has been studied in bulk samples to address economic potential of contained heavy minerals (Force and others, 1976; Stone and Force, 1980), but no detailed mineralogic studies have been done in this depositional environment. In related till and glaciofluvial lithologies, mineralogy has locally been studied (for example, Krynine, 1937). Dreimanis and Vagners (1969) showed that some mineral species in till are concentrated in a "terminal (size) grade," related to the mineral's resistance to glacial abrasion.

This study (1) describes the distribution of heavy minerals in two typical ice-marginal deltaic deposits that overlie contrasting lithologic bedrock terranes and relates the heavy-mineral composition of these sediments to possible sediment sources and dispersal patterns; (2) relates heavy-mineral species to stratigraphic position, grain size, sorting, and sedimentary structures of host sands; and (3) isolates factors affecting hydrodynamic separation of sand grains of different mineralogy in glaciofluvial and deltaic environments. The study thus examines separately the textural and mineralogic immaturity of glacial sediments and includes an account of many heavy-mineral species across the entire sand interval of grain size. By tracking all aspects of lithology (that is, composition, texture, and sedimentary structures), this study explores the interrelation between sediment supply and hydraulic sorting within the deltaic dispersal system.

\section{ICE-MARGINAL GLACIOLACUSTRINE DELTAS}

Tripartite deltaic sequences (Gilbert, 1885), consisting of silty sand bottomset beds, thick sets of inclined sandy to gravelly foreset beds, and gravel topset beds, are the characteristic stratigraphic motif of most ice-marginal deposits of late Pleistocene age in the northeastern United States (examples in Jopling and Walker, 1968; Stone, 1974; Gustavson and others, 1975; summarized by Koteff and Pessl, 1981; Stone and Peper, 1982). This characteristic stratigraphy was produced by progradation of fluvial topset beds over subaqueous sequences of foreset and bottomset beds that were deposited on delta slopes and lake-bottom plains, respectively. The planar contact between delta topset and foreset beds (fig. 1) is at the approximate level of the former lake-water plane, and the approximate paleodepth of any delta foreset sample can be specified from this contact.

The depositional framework of these deltas can be specified from their relict morphology. The delta plains, the

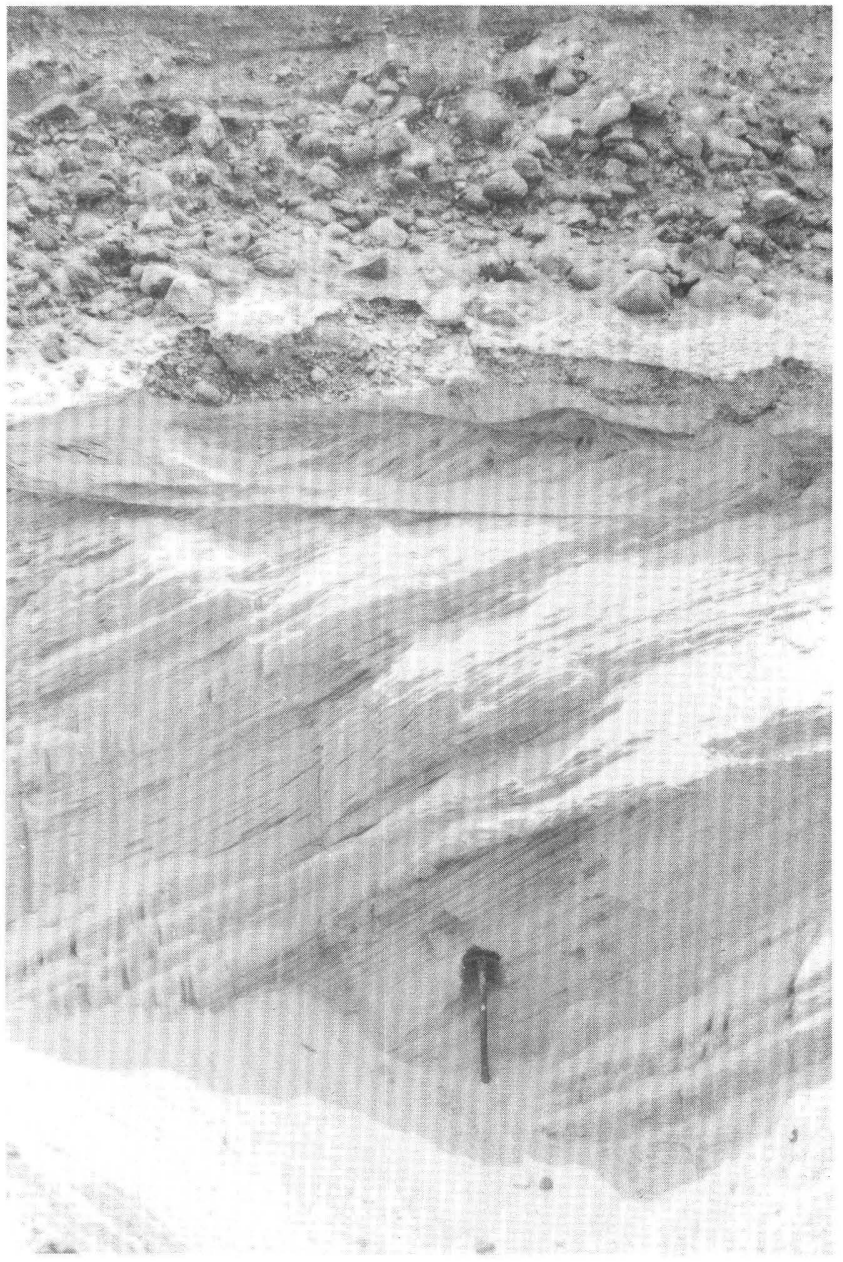

Figure 1. Typical glaciolacustrine delta of the study area, showing topset-foreset disconformity and sets of foreset beds separated by disconformities. Exposure about $5.5 \mathrm{~m}$ high.

upper surfaces of coarse glaciofluvial topset beds, commonly extend from proximal ice-contact slopes to distal digitate borders. The delta foreset slopes beneath these borders merge tangentially with delta toeset slopes or bottomset plains in front of the delta. In many valleys, contacts of successive ice-marginal deltas show the retreatal positions of the edge of a stagnant-ice zone that was marginal to the Laurentide ice sheet. These ice-contact slopes show the trend and some details of the edge of supporting, stagnant-ice walls. The chronology of icemargin recession in late Wisconsinan time (Stone and Borns, 1986) implies that each ice-marginal delta was deposited in no more than a few decades, probably in a few years.

Coarse-grained glaciolacustrine deltas in the region of this study (fig. 2) consist of an overall coarsening-upward sequence of horizontal silty and sandy bottomset beds, overlain by inclined sandy to gravelly foreset beds, which in 


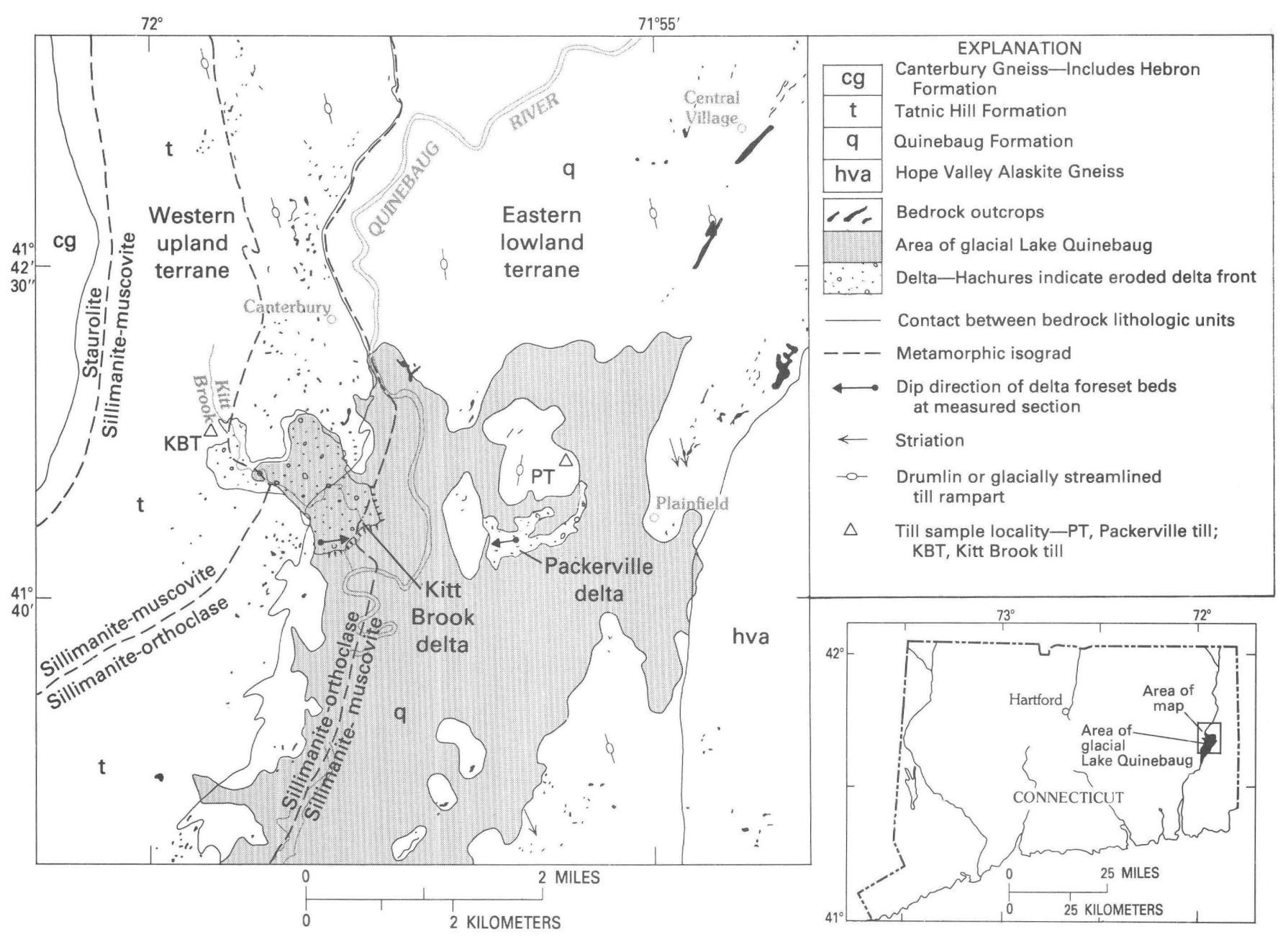

Figure 2. Bedrock geology, metamorphic isograds, and glacial Lake Quinebaug and its deltas.

turn are disconformably overlain by gravel-dominant glaciofluvial delta topset beds (Stone, 1974; Stone and Force, 1982, 1983). The glaciofluvial delta topset gravel facies includes massive to indistinctly bedded, clast-supported, pebble to cobble gravel or even boulder gravel, having locally well-developed imbrication, and pebble or cobble gravel in tabular crossbeds or trough crossbeds. Gravel beds range from 0.2 to $1.2 \mathrm{~m}$ in thickness. Subordinant sand beds are chiefly coarse sand having pebbles and granules in trough and tabular crossbeds. Medium- and fine-sand ripple-laminated beds are locally present.

Deltaic foreset beds characteristically have diverse textures and sedimentary structures. Foreset sequences tens to hundreds of meters downstream from the ice contact of the delta typically are alternating coarse- and fine-sand beds and pebbly sand beds, in thick $(>2 \mathrm{~m})$ sets of foreset cross-strata that are inclined from about $15^{\circ}$ to $30^{\circ}$. In most sections, these inclined strata do not form a simple sequence but consist of multiple sets of foreset beds. Each set of delta foresets is bounded by disconformities but contains conformable beds (Stone and Force, 1982, 1983). These foreset bedding relations are illustrated in measured stratigraphic sections (fig. 3). Local changes in grain size within and between sets of foreset strata imprint a variable pattern on the coarsening-upward textural trend. This overall textural trend in the area of this study is substantiated by augur-hole subsurface data (Stone and Randall, 1978).

Characteristic foreset lithologies include medium- to fine-sand beds having ripple cross-laminations or planar laminations, fine silty sand in sets of draped laminations, and pebbly sands having planar laminations or, less commonly, crossbeds. Steeply dipping pebble to cobble gravel foresets have variable amounts of coarse-sand matrix.

Deltaic foreset sequences consist mostly of sand beds that contain a variety of current bedding features that resulted from traction- and suspended-load deposition on the delta foreset slope (Jopling and Walker, 1968; Aario, 1971; Stone, 1974; Gustavson and others, 1975; Stone and Force, 1982, 1983; Smith and Ashley, 1985). Currents that flowed down and across these foreset slopes were continuous but nonsteady density underflows, or turbidity currents, driven by the mass of their suspended loads. In the upper 


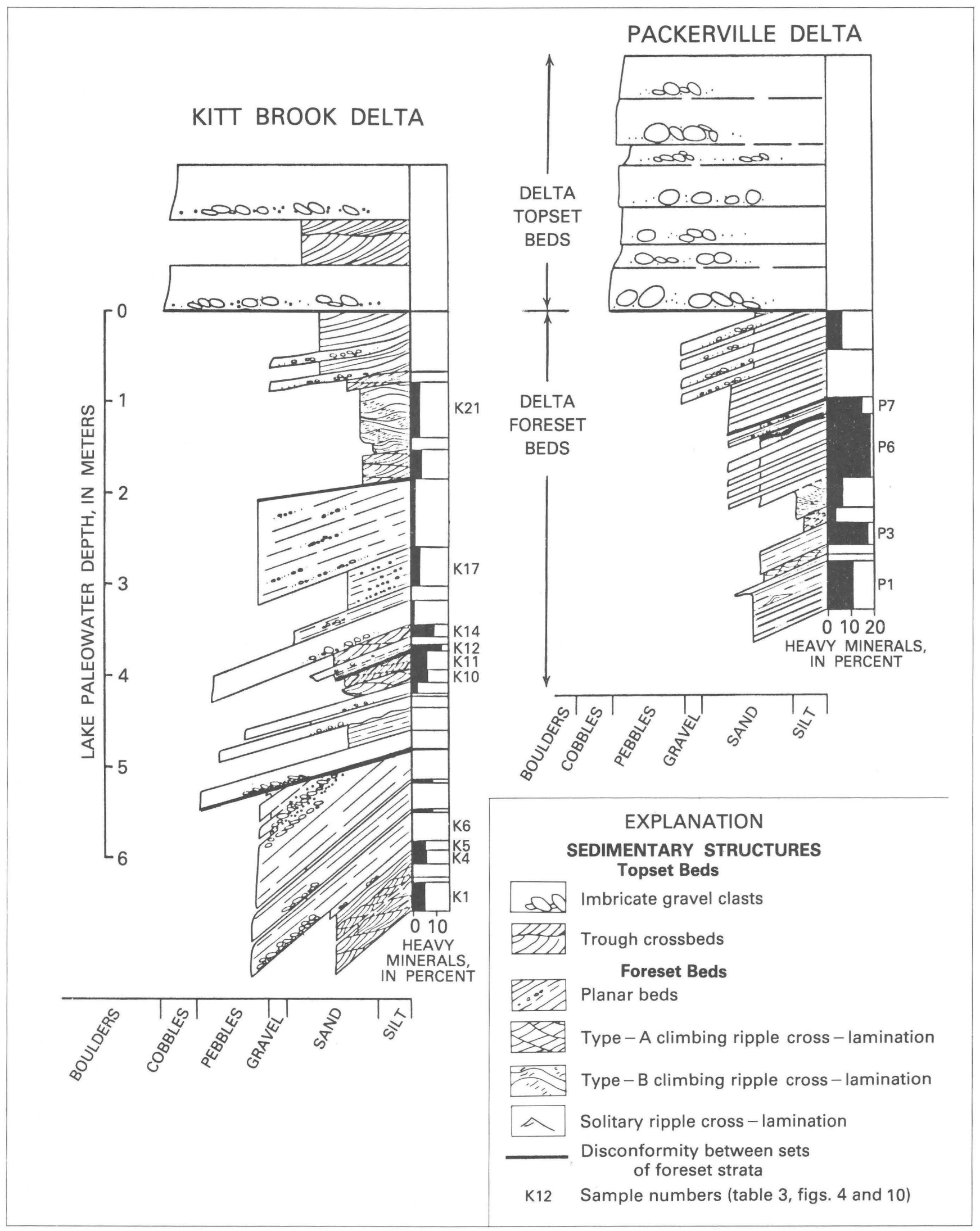

Figure 3. Stratigraphic columns showing sedimentary features and grain size of primary mode. Right column shows the heavy-mineral fraction ( $\rho$ (specific gravity) $>2.85$ ). 
delta foreset sequences in the study area, we have seen no deposits of interflow origin (using criteria of Smith and Ashley, 1985). Lower flow regime bedforms are probably dominant in these sequences and are interbedded with subordinate thinly laminated silt and fine sand that accumulated chiefly from suspended-load fallout. Vertical sequences of climbing ripple cross-laminations consist of gradations from type-A to type-B cross-laminations to draped laminations. Theoretical (Allen, 1971) and experimental (Ashley and others, 1982) studies of such ripple successions indicate that tens of centimeters of these beds probably accumulated in only hours of sedimentation. Sharp contacts between beds and especially between discordant sets of foreset strata indicate erosion related to variable dispersal patterns (Cohen, 1983) on the foreset slope. Gradational or indistinct bed contacts and some sharp contacts probably reflect variability of diurnal and (or) seasonal flow parameters (Smith and Ashley, 1985). Larger bedforms in deltaic subaqueous environments, such as sand megaripples, transverse dunes, and gravel crossbeds, are less common but suggest larger lower flow regime currents. Turbidite beds in the classical sense are present but unusual. In some sections, especially those close to ice-contact proximal parts of deltas, steeply dipping gravel and coarsesand beds accumulated in planar foreset strata. Some of these gravelly foreset beds were probably deposited by continuous avalanching (Allen, 1971) on the upper foreset slope of the delta.

Judging from the distribution of individual deltaic deposits (for example, Stone and Randall, 1978), most sediment was transported less than $3 \mathrm{~km}$ in braided meltwater streams before it was deposited in the various environments of the delta. Most sand was transported through the delta fluvial topset environment and into the foreset depositional environment where subaqueous meltwater currents flowed as density underflows on the foreset slopes. Within the foreset parts of the sequence, we find that many sand or gravel beds are nevertheless quite well sorted especially where particles of the same density are considered. Thus the mineralogic immaturity of these sediments does not necessary imply textural immaturity.

\section{STUDY AREA}

Glacial sediments of late Wisconsinan age form a surficial cover of irregular thickness over the Quinebaug River valley and adjacent uplands of eastern Connecticut (fig. 2), about $70 \mathrm{~km}$ north of the terminal moraine on Long Island. Glacially eroded debris in the Quinebaug River lowland area was transported in a south-southeast direction, as shown by the general direction of striations. Detailed mapping (Stone and Randall, 1978) revealed that glacial and meltwater deposits contain boulders and gravel clasts that are conspicuously similar to lithologies of local bedrock outcrops. In addition, aeroradioactivity maps of the area show that the contoured pattern of radiation, derived from the surficial sediments and subordinate rock outcrop, is similar to the mapped pattern of contrasting bedrock lithologies (Goldsmith and others, 1977). This relation supports the conclusion that most of the glacial sediment was derived locally and was not diluted significantly by far-transported erratic debris. Field relations thus indicate that the mineralogic compositions of glaciogenic deposits should be closely related to the composition of local bedrock.

\section{Bedrock Geology}

The study area is part of a metamorphic belt of Paleozoic age. Detailed bedrock maps of the area (Dixon, 1965; Dixon and Shaw, 1965) show a major north-south lithologic boundary that divides the study area into two gneiss terranes of contrasting mineralogies (fig. 2). Rocks in the western upland terrane are medium-grained leucocratic gneiss and pelitic schist of the Tatnic Hill Formation, minor calc-silicate rocks (Fly Pond Member), and mafic rocks (table 1). Two north-south-trending metamorphic isograds within the Tatnic Hill terrane define the boundaries of a staurolite zone to the west, a sillimanitemuscovite zone in the center, and a sillimanite-orthoclase zone to the east. Thus the Tatnic Hill terrane contains garnet and staurolite to the west and garnet, sillimanite, and local kyanite to the east (table 2). Small but mappable calcsilicate units contain abundant pyroxene (mostly diopsidic), amphibole (mostly hornblende), epidote, and sphene.

Rocks of the eastern terrane that underlie the Quinebaug lowland are dark, fine- to medium-grained hornblende gneiss of the Quinebaug Formation and minor leucocratic gneiss units. Most of the Quinebaug Formation is within a sillimanite-muscovite zone, and its dense minerals include amphibole (hornblende), lesser amounts of pyroxene, finegrained garnet and epidote, and minor sphene and sillimanite (table 2).

Rocks of both terranes contain opaque magnetite and ilmenite; leucocratic units in each terrane contain a minor amount of zircon. In both terranes, rutile is present in sillimanite-muscovite-grade or, more commonly, sillimaniteorthoclase-grade rocks (Goldsmith and Force, 1978).

H.R. Dixon (written commun., 1985) has estimated the average percentage of heavy minerals from about 100 thin sections of rocks from each terrane. Her estimates, converted to weight percentages, are about 34 percent (plus 10 percent biotite) for the Quinebaug Formation and 15 percent (plus 14 percent biotite) for the Tatnic Hill Formation. Minerals are ranked by abundance in table 2 .

\section{Glacial Deposits}

Glacial sediments of the area consist of thin till and local meltwater deposits on the bedrock uplands and numer- 
Table 1. Rock-type comparisons of bedrock and gravel samples, glacial Lake Quinebaug

[Rock types are modified by principal minerals (Dixon, 1965), listed in increasing order. Accessory minerals are shown in parentheses. Bedrock rock types are listed in order of outcrop area and proximity to ice-contact source of sediments in deltaic deposits. Map unit symbols are from Dixon (1965)]

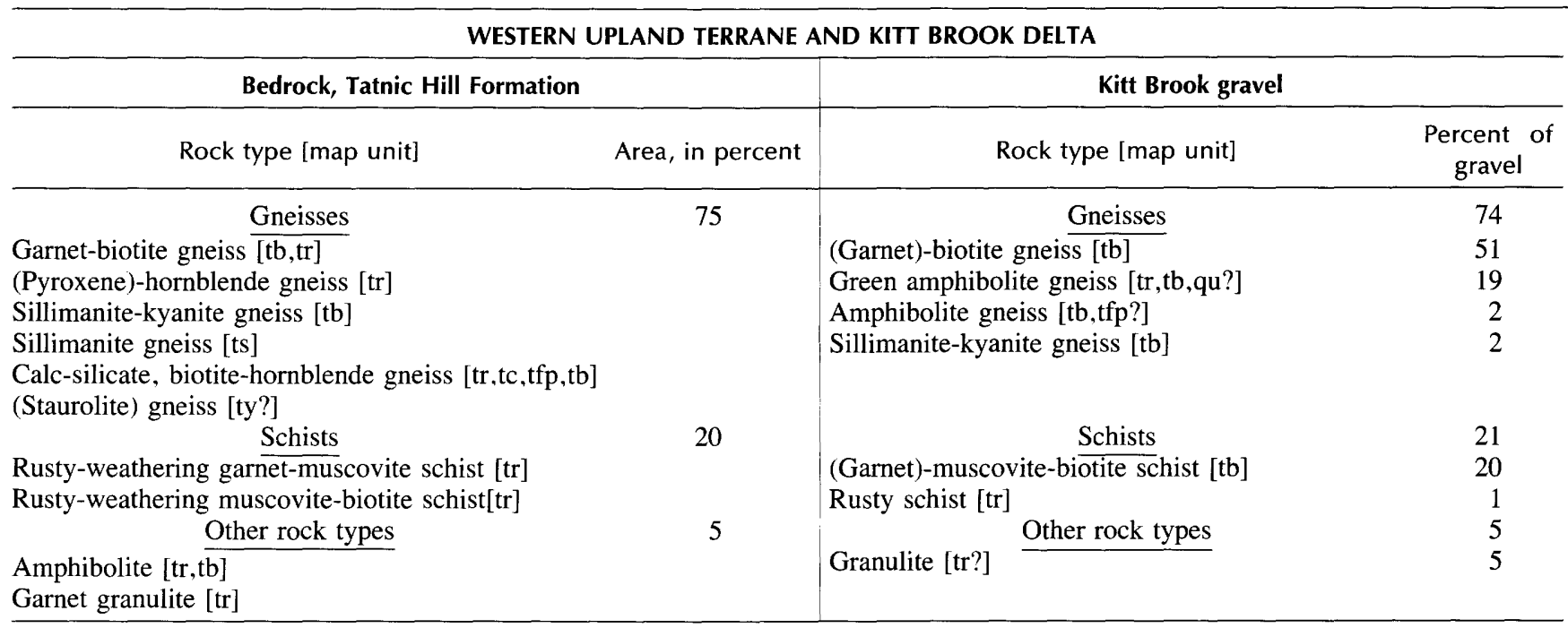

EASTERN LOWLAND TERRANE AND PACKERVILLE DELTA

\begin{tabular}{l|r}
\hline \multicolumn{1}{c|}{ Bedrock, Quinebaug Formation } & \multicolumn{1}{c}{ Packerville gravel } \\
\hline \multicolumn{1}{c|}{ Rock type [map unit] } & Rock type [map unit]
\end{tabular}

ous deltaic deposits on the Quinebaug lowland. Till derived from the resistant gneiss of the Tatnic Hill Formation is sandy; the matrix of sand and finer grain sizes from our one sample contains 25 percent silt and clay. A slightly siltier till, which overlies bedrock in the lowland, has a matrix which contains 35 percent silt and clay.

Glaciolacustrine deposits in the Quinebaug lowland consist of a series of ice-marginal deltas deposited in glacial Lake Quinebaug (Stone, 1978; Stone and Randall, 1978). Lake Quinebaug extended as a proglacial lake from its bedrock-floored spillway at the narrow southern part of the valley (fig. 2) to the northern part of the basin where it was about $5 \mathrm{~km}$ wide. Ice-marginal deltas, related to six retreatal positions of the margin of the ice sheet, prograded into the lake as the margin retreated northward. Delta topset-foreset contacts indicate the altitude of the isostatically tilted lakewater plane, at the maximum extent of the lake, shown in figure 2. Bedrock-surface contours on the bottom of the basin (Stone and Randall, 1978) show that the lake was generally less than $35 \mathrm{~m}$ deep. Ice-marginal deltas were deposited on the sides of the basin or near bediock islands where the lake was 10 to $20 \mathrm{~m}$ deep. Lake-bottom sand is not extensive but is distributed around and between some of the deltas.

The two ice-marginal deltaic deposits studied in this report are in the northern part of the lake basin (fig. 2). The 
Table 2. Relative abundance of heavy minerals in bedrock terranes, tills, and delta channel samples, Kitt Brook and Packerville deltas

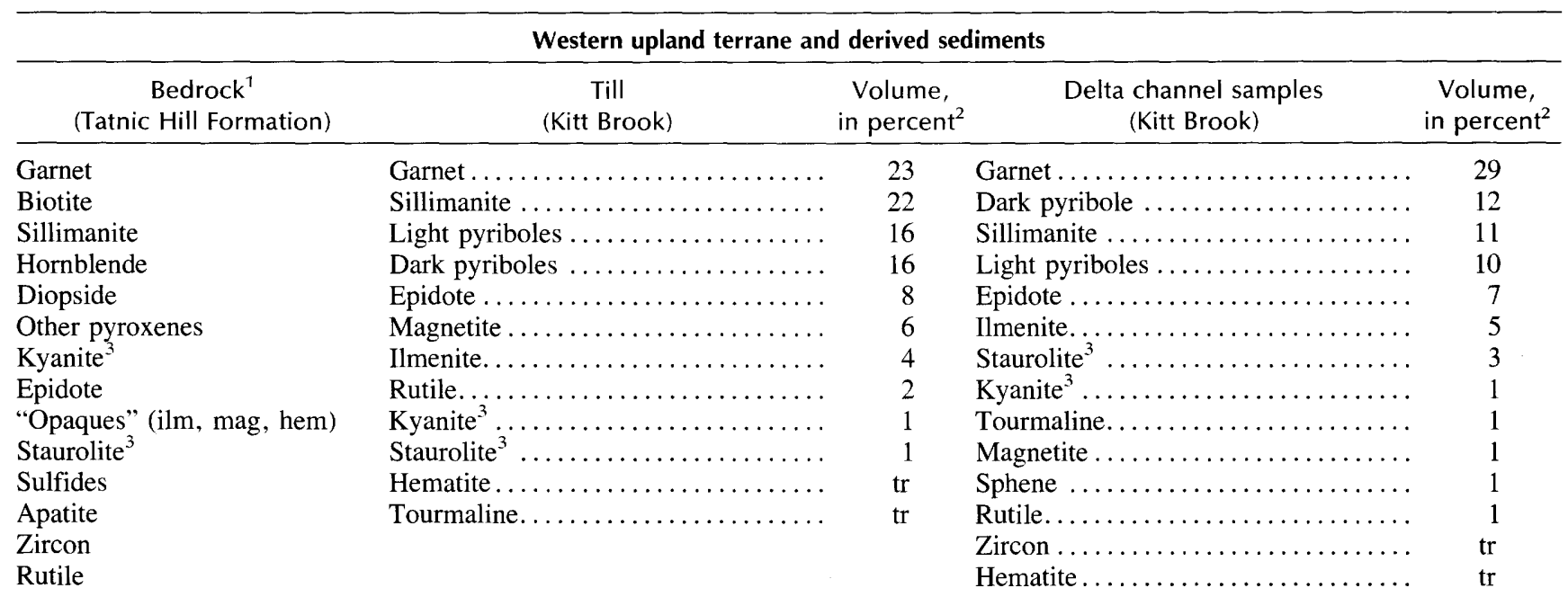

\begin{tabular}{|c|c|c|c|c|}
\hline \multicolumn{5}{|c|}{ Eastern lowland terrane and derived sediments } \\
\hline $\begin{array}{c}\text { Bedrock }^{1} \\
\text { (Quinebaug Formation) }\end{array}$ & $\begin{array}{c}\text { Till } \\
\text { (Quinebaug) }\end{array}$ & $\begin{array}{l}\text { Volume, } \\
\text { in percent }\end{array}$ & $\begin{array}{c}\text { Delta channel samples } \\
\text { (Packerville) }\end{array}$ & $\begin{array}{l}\text { Volume, } \\
\text { in percent }^{2}\end{array}$ \\
\hline Hornblende & Dark pyribole ........ & 33 & Dark pyribole & 35 \\
\hline Epidote & Epidote $\ldots \ldots \ldots \ldots \ldots \ldots \ldots \ldots$ & 24 & Epidote ....... & 17 \\
\hline Biotite & Garnet..$\ldots \ldots \ldots \ldots \ldots \ldots \ldots$ & 18 & Light pyribole $\ldots \ldots \ldots \ldots \ldots \ldots \ldots$ & 13 \\
\hline Diopside & Light pyribole $\ldots \ldots \ldots \ldots \ldots \ldots \ldots$ & 11 & Garnet $\ldots \ldots \ldots \ldots \ldots \ldots \ldots \ldots$ & 11 \\
\hline Garnet & Sillimanite.$\ldots \ldots \ldots \ldots \ldots \ldots \ldots$ & 7 & Sillimanite $\ldots \ldots \ldots \ldots \ldots \ldots \ldots$ & 5 \\
\hline "Opaques" & Ilmenite. $\ldots \ldots \ldots \ldots \ldots \ldots \ldots \ldots$ & 3 & Magnetite $\ldots \ldots \ldots \ldots \ldots \ldots \ldots \ldots$ & 5 \\
\hline Allanite & Magnetite ..................... & 3 & Ilmenite $\ldots \ldots \ldots \ldots \ldots \ldots \ldots \ldots \ldots$ & 3 \\
\hline Sphene & Sphene $\ldots \ldots \ldots \ldots \ldots \ldots \ldots \ldots$ & 1 & Tourmaline.................... & 1 \\
\hline Zircon & Rutile.$\ldots \ldots \ldots \ldots \ldots \ldots \ldots \ldots \ldots$ & 1 & Sphene $\ldots \ldots \ldots \ldots \ldots \ldots \ldots \ldots \ldots$ & 1 \\
\hline Apatite & Kyanite $^{3}$.. & 1 & Rutile $\ldots \ldots \ldots \ldots \ldots \ldots \ldots \ldots \ldots$ & $\operatorname{tr}$ \\
\hline Rutile & Zircon $\ldots \ldots \ldots \ldots \ldots \ldots \ldots$ & $\operatorname{tr}$ & Zircon $\ldots . . \ldots$ & $\operatorname{tr}$ \\
\hline & Corundum $\ldots \ldots \ldots \ldots \ldots \ldots \ldots$ & $\operatorname{tr}$ & Kyanite $^{3} \ldots \ldots \ldots \ldots \ldots \ldots \ldots$ & $\operatorname{tr}$ \\
\hline & Tourmaline...$\ldots \ldots \ldots \ldots \ldots \ldots$ & $\operatorname{tr}$ & Corundum $\ldots \ldots \ldots \ldots \ldots \ldots \ldots$ & $\operatorname{tr}$ \\
\hline
\end{tabular}

\footnotetext{
${ }^{1}$ Listed in apparent order of abundance by volume.

${ }^{2}$ Listed in volume percent of heavy minerals, exclusive of biotite, to facilitate comparison to bedrock. Values rounded to whole percent, tr $<1$ percent.

${ }^{3}$ Minerals that have sources restricted to the western terrane.
}

Kitt Brook delta is on the western side of the lowland; related ice-contact deposits and coarse glaciofluvial sediments that were deposited at the ice-marginal source of the delta extend up into the upper reaches of Kitt Brook in the western upland terrane. The Packerville delta, $2.5 \mathrm{~km}$ east of the Kitt Brook delta, is in the axial part of the Quinebaug lowland in the eastern lowland terrane. The deposit was fed by ice-channel streams in stagnant ice that fringed the front of the ice sheet in the lowland. The delta contains a broad, ice-contact-bounded linear ridge of ice-channel origin. The positions of both deltaic deposits, altitudes of delta topsetforeset contacts within each section, and stratigraphic relations of lake-bottom sediments clearly show that sediments in each delta were deposited in glacial Lake Quinebaug. The two units are related to retreatal ice-margin positions that are closely related in relative age (Stone and Randall, 1978).

\section{METHODS OF THIS STUDY}

Measured stratigraphic sections (fig. 3) include the exposed upper foreset and topset beds of each delta. At least one sample was taken from each bed, except those beds less than $1 \mathrm{~cm}$ thick. A channel sample from each delta integrated lithologies from the entire foreset sequence. Grain-size analyses were based on standard sieving procedures at $1 / 2-\phi$ intervals in sandy beds, and results were expressed in weight percent. For purposes of heavy-mineral identification, a bromoform-separated (specific gravity $(\rho)$ 2.85 ) coarse fraction, 1 to $2.5 \phi$, and fine fraction, 2.5 to $4.0 \phi$, were reseparated by using methylene iodide ( $\rho 3.3$ ), and each of the four size-density fractions was separated into five magnetic subfractions. Each subfraction was weighed and examined under binocular and petrographic microscopes. The relative abundance of each mineral 
Table 3. Mineral percentages by weight in some heavy-mineral ( $\rho$ (specific gravity) $>2.85$ ) concentrates of the most completely analyzed samples, Kitt Brook and Packerville deltas

[K samples from Kitt Brook; P samples from Packerville; -, not identified]

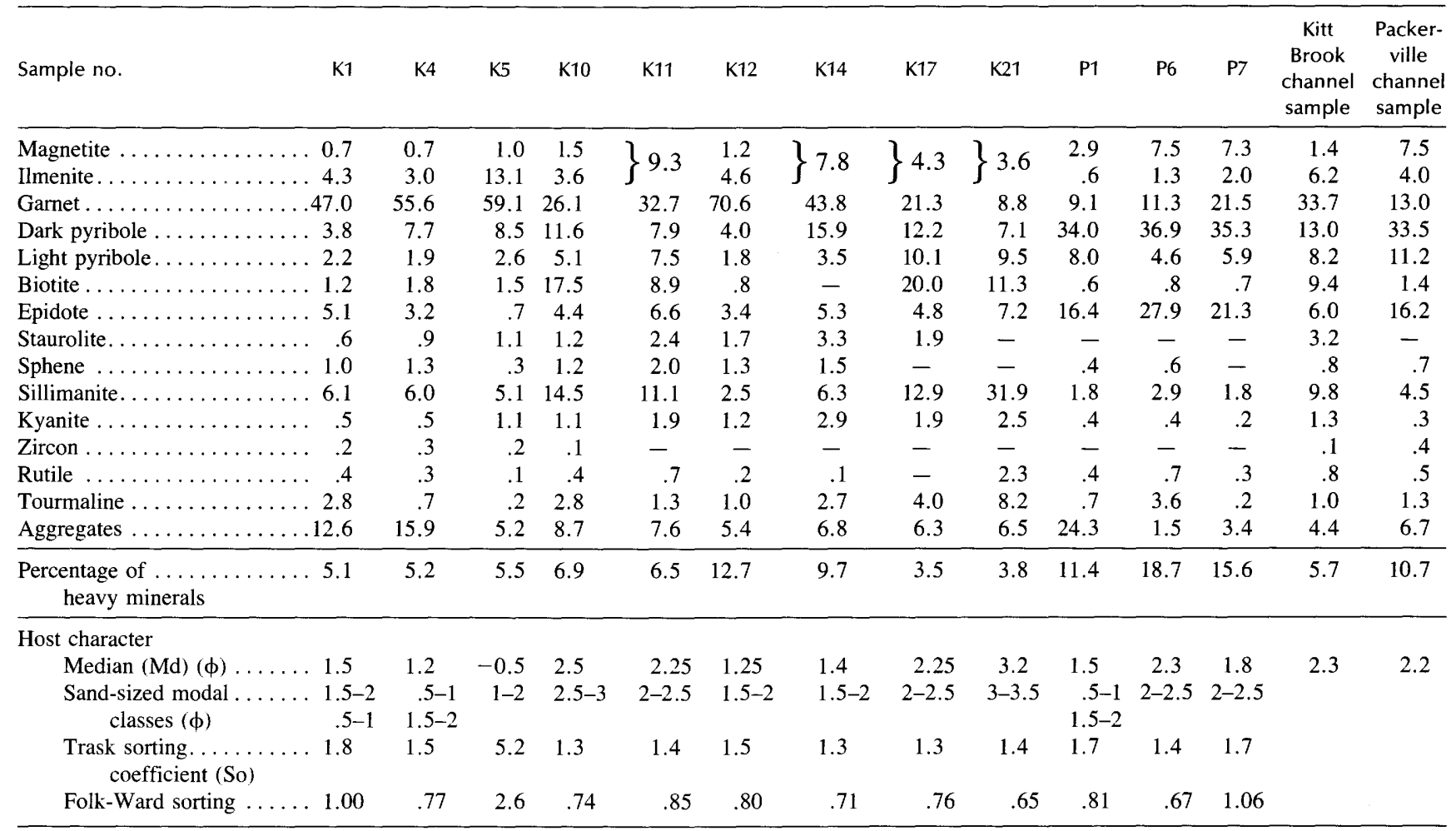

species was estimated by point counts and visual comparison charts. The weight of each mineral species, adjusted for specific gravity, was then summed for all 20 size, density, and magnetic fractions to determine the weight percentage of each mineral in each sample (table 3 ). For sample K12, and for the channel samples and two till samples, more work was done; heavy minerals were separated by magnetism and density and identified by point counts for each $1 / 2-\phi$ grain-size split. These intricate procedures thus relied as much as possible on weighed fractions based on physical properties, and as little as possible on point counting, for which error is much larger.

Sources of error included small errors in weighing and significant-figure errors, errors from sample separation, and errors associated with point counts. In most samples, errors due to incomplete density separations were less than 10 percent; these were corrected in counted samples. The largest source of error was estimation of mineral abundance by point-count (150 to 320 grains per fraction) methods. Weight percentage of magnetite was established by magnetic properties and was not subject to point-count error. For sparse minerals having lower magnetic susceptibilities, such as rutile, probable errors are as much as 50 weight percent of listed mineral abundance.

\section{STRATIGRAPHIC SECTIONS}

The measured sections in both deltas are composite, because of the method of quarrying in benches. Both measured sections show horizontally bedded glaciofluvial gravel and sand beds that disconformably overlie dipping delta foreset strata (fig. 3). The foresets consist of sets of conformable beds separated by angular discordances. True dip angles of foreset beds are shown in figure 3. No delta bottomset beds were exposed in either pit, so the total thickness of foreset beds is not known.

\section{Kitt Brook Delta}

The Kitt Brook delta was deposited at the western margin of Lake Quinebaug (fig. 2). Ice-marginal meltwater streams drained the upper Kitt Brook drainage in the western upland Tatnic Hill terrane, and the delta prograded eastward into the lake. High-angle reverse and normal faults downthrown to the east are exposed in the pit wall and indicate that the delta accumulated in contact with melting ice that was marginal to the edge of the ice sheet.

Gravel beds in the delta topset sequence total $1.6 \mathrm{~m}$ in thickness (fig. 3). Cobble clasts are as large as $12 \mathrm{~cm}$ 

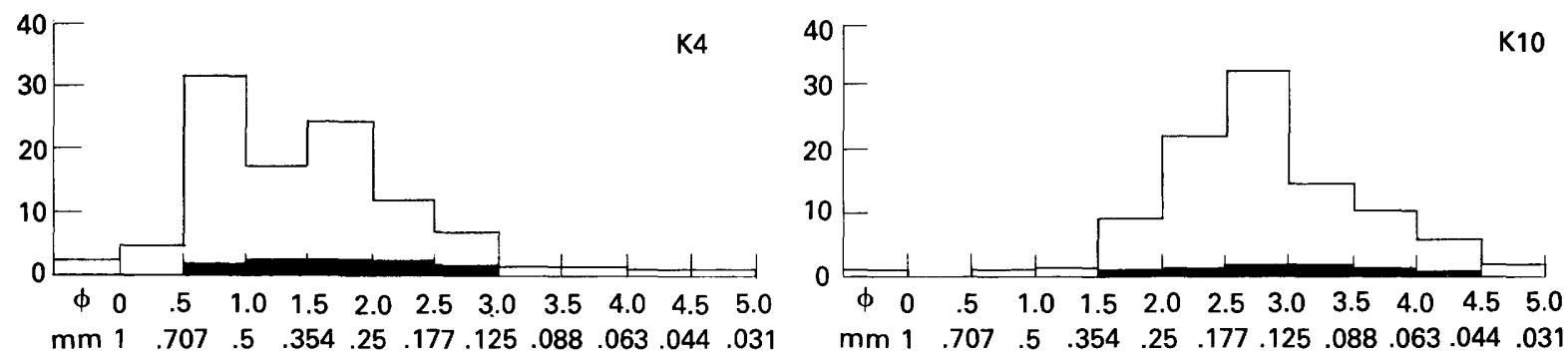

KITT BROOK GRAVELS
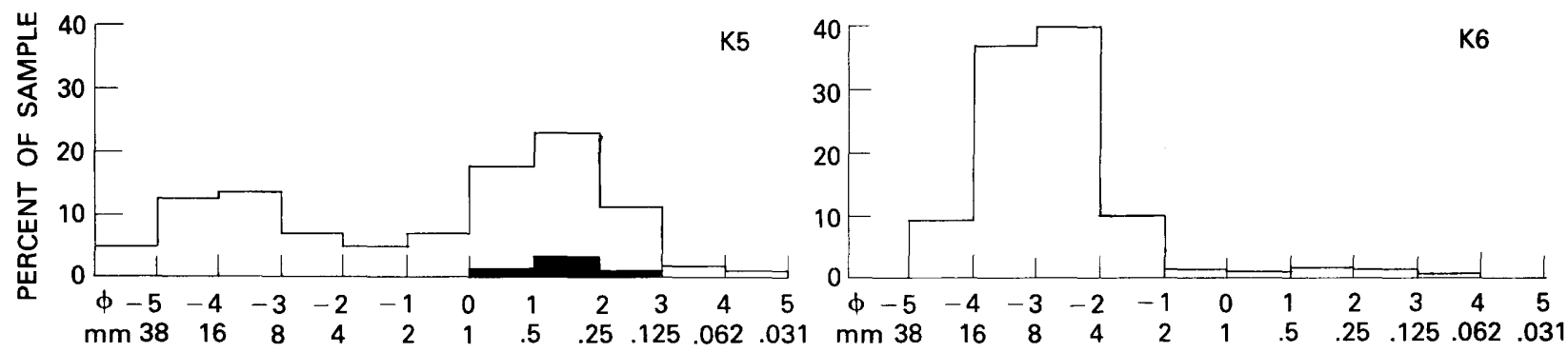

PACKERVILLE SANDS
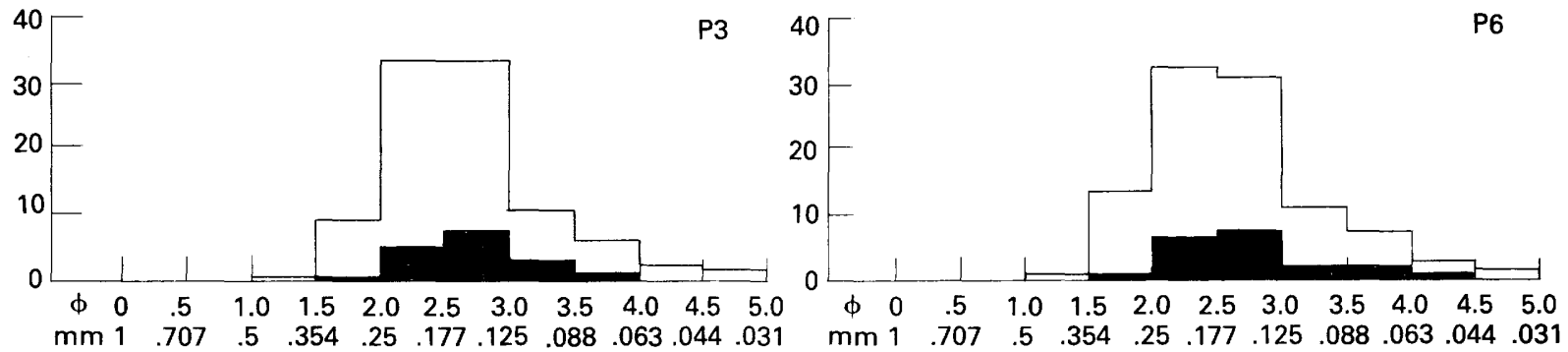

GRAIN SIZE, IN PHI (申) AND MILLIMETERS $(\mathrm{mm})$

Figure 4. Grain-size histograms for light and heavy minerals (dark pattern) of six beds. Note differing scale and $\phi$ spacing for sands and gravels. K10 is a typical ripple-laminated fine sand; K4 is a typical planar-laminated bimodal coarse sand; $\mathrm{K} 6$ is an unusual openwork gravel having few heavy minerals; $\mathrm{K} 5$ is a typical bimodal gravel, here framework supported; P6 is a typical ripple-laminated fine sand; P3 is a typical planar-laminated fine sand.

intermediate diameter. Scoured bases of channels show an east-southeasterly paleocurrent direction. The delta topset beds disconformably overlie $4.7 \mathrm{~m}$ of delta foreset beds that consist of four sets of east- or northeast-dipping foreset strata. The sets of foreset strata are separated by erosion surfaces. In the foreset sequence, sand beds predominate over gravel beds. Two sets of foreset strata coarsen upward, another shows no definite vertical trend in texture, and one set fines irregularly upward. From bottom to top, this composite foreset sequence becomes finer grained.

The lowest set of foreset beds coarsens upward and dips $40^{\circ}$. The lowest beds measured in the set are medium sand and contain two vertical sequences of type-A climbing ripple cross-laminations and overlying draped laminations.
These beds are overlain by a thin bed of planar-laminated medium sand ( $\mathrm{K} 4 \mathrm{of} \mathrm{fig.} \mathrm{4).} \mathrm{These} \mathrm{sequences} \mathrm{have} \mathrm{average}$ total heavy-mineral contents of 5 to 6 percent. Bimodal gravel and sand beds overlie the rippled sequences (K5 of fig. 4). The sand grain-size mode is similar to the mode of the underlying sand beds. A set of openwork, imbricate gravel beds is at the top of this set of foresets (K6 of fig. 4). Pebbles in these beds are as long as $7 \mathrm{~cm}$, and the gravel grain-size mode of these beds is similar to the gravel mode of the underlying bimodal beds. Both the openwork gravel and the rippled sands are moderately well sorted (sorting coefficient (So) 1.6).

The second set of foreset beds fines upward and consists of interbedded sand and gravel in $0.1-$ to $0.3-\mathrm{m}$ 
beds dipping $16^{\circ}$. The sands are well sorted (So about 1.4), are fine (median $(\mathrm{Md})$ about $2.25 \phi$ ), and have planar and type-A ripple laminae (K10 of fig. 4). Heavy-mineral contents average about 6.5 percent. The gravels in this set are poorly sorted (So 4.5 ) and have poorly defined modes. Imbricate pebbles are as long as $14 \mathrm{~cm}$. The heavy-mineral content of the gravel beds is low. Bases of gravel beds are minor erosional surfaces; sand beds commonly overlie silt drapes.

Beds in the third set of foresets dip $21^{\circ}$. At the base is a thin bed of planar laminated coarse to medium sand that contains 12.5 percent total heavy minerals (K12). Overlying beds consist of interbedded sand and gravel beds separated by sharp erosional contacts. Some sand beds are granular and contain trough crossbeds. These sands are well sorted (So 1.3-1.4) and contain 3 to 10 percent heavy minerals. Interbedded gravel beds are poorly sorted and have indistinct modes. Clasts are as long as $8 \mathrm{~cm}$. The heavy-mineral content of the gravel beds is only 1 to 2 percent.

The uppermost set of foreset beds coarsens upward and consists almost entirely of well-sorted (So 1.4) sand. The very fine sand beds at the base contain a type-A to typeB climbing ripple cross-lamination vertical sequence. This sequence is disconformably overlain by a thin bed of fine sand containing type-A ripples. Granular coarse sand in planar beds overlies this bed and extends to the base of the topset beds. The dip of these foreset beds is $9^{\circ}$. Heavymineral content of the lower beds averages about 4 percent.

The composition of the sediments in the Kitt Brook delta is closely related to the known bedrock lithologies of the western upland terrane. Pebbles in the foreset sequence of the Kitt Brook delta (table 1) are composed chiefly of banded (garnet)-biotite gneiss, similar to the dominant rock type of the Tatnic Hill Formation. Other pebble lithologies, such as green amphibole gneiss, (garnet)-muscovite-biotite schist, and rusty schist are also common minor rock types of the Tatnic Hill Formation.

The mineral composition of sand in the Kitt Brook delta also compares closely with bedrock of the western upland terrane and with a local till sample (table 2). The channel sample of the Kitt Brook foreset sequence has a median grain size of $2.3 \phi$ and contains 5.7 percent heavy minerals.

Heavy-mineral pan concentrates from the Kitt Brook delta sands are pink, because of abundant garnet. The heavy-mineral assemblages in all bed samples from the Kitt Brook delta sediments are broadly similar; they are dominated by garnet and lesser components of sillimanite, ilmenite, and biotite (table 3). Pyriboles and epidote also are ubiquitous components. Staurolite, unique to the western bedrock terrane, is a characteristic constituent and is zoned in coarse grains. Variation in the heavy-mineral suite from bed to bed is closely related to varying bed grain size (table 3). The assemblage of heavy minerals in the channel sample (table 3) integrates the bed-by-bed variation and is therefore representative of the suite of sand-sized minerals that were supplied to meltwater streams throughout deposition of the upper part of the delta.

\section{Packerville Delta}

The Packerville delta was constructed over a shallow bedrock area in the axial northern part of Lake Quinebaug. The hills north of the deposit were islands in the lake (fig. 2 ). These hills and the surrounding lowland area are underlain by the Quinebaug Formation. The delta prograded westward within an ice-channel drainage system.

Topset strata in the Packerville delta comprise pebble-cobble gravel beds that total $2.8 \mathrm{~m}$ in thickness (fig. 3 ). Three sets of foreset strata, separated by disconformities and totaling $3.3 \mathrm{~m}$ in thickness, disconformably underlie the topset beds. The entire foreset sequence coarsens upward from sand beds in the lowest set to interbedded sand and gravel in the uppermost set. Only the uppermost set coarsens upward internally.

The lowest set of foreset strata, dipping $24^{\circ}$, consists of interbedded ripple-laminated sand (mostly type-A) and planar-bedded sand. The grain-size range of the ripplelaminated sands (Md 2.0 to $4.0 \phi$; fine and very fine sand) overlaps the grain-size range of the planar-bedded sands (Md 1.5 to $2.3 \phi$; medium and fine sand). Grain-size distributions of samples P3 and P6 are shown on figure 4. Sorting of most beds is good (So about 1.3 except for samples taken over several laminae). Heavy-mineral contents range from 3.7 to 18.8 percent; both ripple- and planar-laminated beds have high values.

The middle set of foresets was measured near the edge of the set where it is thin. In the measured section, this erosionally bounded set consists of sand and pebbly sand beds and contains 15.6 percent heavy minerals.

The upper set of foreset strata dips $22^{\circ}$ and consists of a coarsening-upward sequence of sand and pebbly sand beds, the latter strongly bimodal and consequently poorly sorted (So 4.1).

Lithologies of pebbles in the Packerville foreset beds are dominated by dark gneiss from the Quinebaug Formation, including banded pyribole (chiefly hornblende) gneiss, (garnet)-biotite gneiss, granulite, and minor pelitic lithologies. Granitoid rocks and leucocratic gneiss make up 19 percent of the clasts; these lithologies may have been derived from the upland terrane to the east, as well as from leucocratic layers in the Quinebaug Formation.

The mineralogy of Packerville sands also reflects derivation from the Quinebaug Formation and is similar to that of a local till sample (table 2). The channel sample of the entire Packerville foreset sequence has a median grain size of $2.2 \phi$ and contains 10.7 percent heavy minerals. 
Heavy-mineral pan concentrates from Packerville delta sands are green, reflecting a dominance by pyriboles and epidote. The assemblage of heavy minerals, broadly similar throughout the Packerville section, is dominated, in order of abundance, by pyribole (mostly hornblende), epidote, and garnet, and a ubiquitous lesser component of magnetite (table 3). Staurolite was not identified in the Packerville sediments, and ilmenite, biotite, and sillimanite are far less abundant than in the Kitt Brook delta. Variation in mineralogy between beds is related to grain size (table 3 ). The channel sample represents the suite of sand-sized minerals supplied to the Packerville delta during sedimentation of the exposed foreset sequence. The suite contrasts strongly in mineral proportions and sizes with the mineral suite of the Kitt Brook delta (table 3).

\section{General Comparison of Textures and Bedding}

The foreset sequences of the two deltas are texturally similar except that the Kitt Brook delta has a greater proportion of gravel beds. The median grain size of the sand fraction of the Kitt Brook channel sample, $2.3 \phi$, is virtually identical to the median value, $2.2 \phi$, of the Packerville channel sample. Figure 4 presents some typical grain-size distributions of beds from both deltas, including bimodal gravelly beds.

Sorting coefficients of the foreset beds range from 1.3 (well sorted) to 5.2 (poorly sorted) (table 3) in Trask's (1932) terminology. Folk and Ward (1957) sorting coefficients are 0.65 to 2.6 . The better sorted beds, having So values of 1.6 or less, include beds of openwork gravels, grits, and coarse and fine sands and constitute well over half of the foreset sequences in both deltas. Sand beds having either planar- or ripple-laminated structures have So values as low as 1.3, although some planar-bedded sands have higher So values because of a tendency toward a subsidiary coarse mode.

There is some correspondence between sedimentary structure and grain size. Ripple-laminated beds have median grain sizes that range from 1.4 to $4.0 \phi$, and planar-laminated beds have median grain sizes that range from -0.25 to $2.3 \phi$. The overlap is thus in the medium and fine sands (fig. 5). The coarsest sands that contain ripple laminae are in the Kitt Brook section.

\section{HEAVY-MINERAL DISTRIBUTION}

\section{General Character of Heavy-Mineral Grains}

Heavy-mineral grains in both deltaic sequences are fresh and angular to subangular, and some species are euhedral. Jagged grain edges and sharp conchoidal fractures are preserved on most grains. Subrounded grains constitute only a small proportion of the heavy-mineral suites. Magnetite is octahedral in most grains of all grain sizes. A few grains of garnet contain euhedral faces. Minerals that have prismatic habit, such as tourmaline, are either euhedral or show broken terminations. Light-mineral grains are unweathered and are angular or subangular, commonly preserving conchoidal fractures or cleavage faces. The morphology of virtually all sand-sized mineral constituents thus clearly shows the first-cycle origin of these glacial sediments. Heavy minerals are present largely in polymineralic rock fragments in gravel-sized fractions and to a lesser extent even in the very coarse sand-sized fraction. In fractions finer than 0.0 to $1.0 \phi$, heavy minerals occur predominantly as separate grains. Heavy-mineral-bearing polymineralic rock aggregates persist as minor constituents in grain sizes as fine as $3.0 \phi$.

\section{Heavy-Mineral Assemblages and Sediment Sources}

The assemblages of heavy minerals in samples from each delta are relatively homogeneous, the relative abundance of minerals varying with differences in grain size (table 3). Between the two deltaic sections, proportional abundances of heavy minerals are strikingly different. The most obvious difference is in the variation of dominant minerals. For example, the ratio of garnet to pyribole + epidote in the Kitt Brook delta ranges from 7.7 in the coarsest sample (K12) to 0.37 in the finest sample (K21); this ratio is 1.24 for the Kitt Brook channel sample. In the Packerville sequence this ratio ranges from 0.16 to 0.34 and is 0.21 for the channel sample. The contrast between deltas is also exemplified by the ratio of ilmenite to magnetite. In the Kitt Brook samples, this ratio ranges from 2.4 to 13.1 (4.4 in the channel sample), whereas in the Packerville sediments, this ratio ranges from 0.17 to 0.27 (0.53 in the channel sample). Biotite, sillimanite, and kyanite are common in the Kitt Brook section but are notably less important in the Packerville sequence. Staurolite is common in Kitt Brook samples but was not observed in Packerville samples. Varietal mineral characters also are distinct; for example, many epidote grains in samples from Packerville contain magnetite inclusions.

Each deltaic deposit contains a characteristic suite of heavy minerals that is similar to the mineral suites from the adjacent bedrock terrane and local till samples (table 2). Garnet is the principal mineral in Kitt Brook sediments, especially in coarse-sand samples. Its abundance is attributed to the corresponding abundance of coarse-grained garnet in rocks of the Tatnic Hill Formation. In the rocks of the eastern lowland terrane, garnet is a lesser and finegrained constituent and is found chiefly in the fine fraction of the Packerville samples. Pyribole (mostly hornblende) and epidote are the predominant minerals in the dark gneissic rocks of the Quinebaug Formation and are also the 

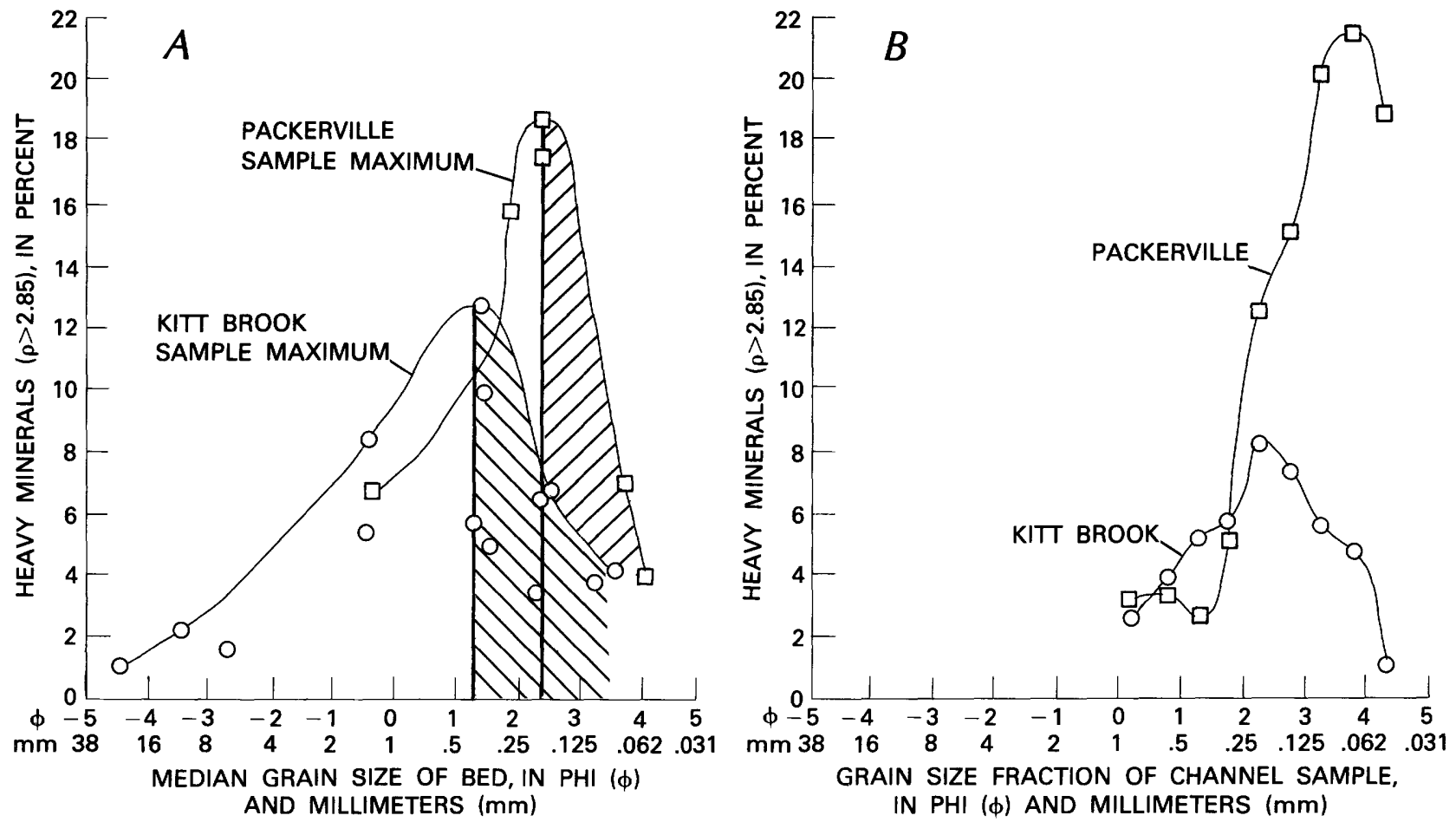

Figure 5. Heavy-mineral content as a function of grain size. $A$, Heavy-mineral content of sands of differing median grain sizes. Grain sizes of rippled beds in each delta are delineated by diagonal lines. Table 3 shows the relation of median to modal grain size of these sands. $B$, Heavy-mineral content of grain-size classes in the channel samples. Open circles, Kitt Brook samples; open squares, Packerville samples; $\rho$, specific gravity.

predominant constituents of the Packerville samples. Pyribole in Kitt Brook sand was probably derived from the Fly Pond Member and other calc-silicate or mafic units within the Tatnic Hill Formation. The small amount of sillimanite in samples from Packerville may have derived from reportedly sparse (Dixon, 1965) sillimanite-bearing lenses of the Quinebaug Formation. The presence and relative abundance of all other mineral species likewise are related to the mineralogic composition of the bedrock terranes. Thus, only limited mixing of minerals across the bedrock terrane boundary is indicated.

The distribution of pyribole, sillimanite, and kyanite (tables 2, 3) could be interpreted as a result of limited mixing of sand by transport across the bedrock terrane boundary, either by glacial or fluvial processes. Some cross-boundary transport is expected. However, the presence of staurolite in the Kitt Brook samples, and its absence in the sand at Packerville, suggests that such crossboundary sediment mixing is minimal in the study area. Staurolite in Kitt Brook delta sands is derived from the part of the Yantic Member of the Tatnic Hill Formation that is at staurolite metamorphic grade (Dixon, 1964, written commun., 1979; Dixon and Shaw, 1965); staurolite is absent in rocks to the east due to higher metamorphic grade.

The total heavy-mineral abundance in the channel samples further contrasts the two deltaic sections. At Kitt
Brook, the total heavy-mineral content in the sand fraction is 5.7 percent. At Packerville, heavy minerals make up 10.7 percent of the sand. Because the grain-size distributions of the channel samples are nearly identical, the difference in heavy-mineral contents cannot be attributed to differences in sample texture. The contrasting heavy-mineral contents of the two deltas correspond to differences in abundance of dense minerals in source rock terranes. Minerals denser than $\rho 2.85$ average about 15 percent by weight in the Tatnic Hill Formation. Such minerals average about 34 percent in the Quinebaug Formation. This contrast is reflected in the heavy-mineral contents of local till; our sample of Kitt Brook till contains 7.9 percent, whereas our Quinebaug till sample contains 10.1 percent. No overall concentration of heavy minerals is apparent in the sand of either delta. In fact, sand fractions of these coarse deltaic sediments are enriched in quartz and feldspar relative to bedrock.

\section{Heavy-Mineral Distribution Within the Deltas}

The abundance of heavy minerals shows no systematic relation to stratigraphic position in the foreset sequences (fig. 3). Because the topset-foreset contact represents the former lake surface, there is no correlation between heavy-mineral content and paleowater depth. 
There is no systematic distribution of minerals within individual sets of foreset strata, with the exception of one thin enriched unit, sample K12, which is above an unconformity at the base of a set. Sedimentary structure likewise appears to have little influence on heavy-mineral content in samples of equal grain size. Sands that have higher heavymineral content in each section may be planar- or ripplelaminated or crossbedded (fig. 5).

\section{Influence of Grain Size}

Total heavy-mineral content. - The highest heavymineral contents in the Packerville section (fig. 5A) are in sand beds having median grain-size diameters of 1.8 to 2.3 $\phi$ (medium to fine sand), whereas in the Kitt Brook section heavy minerals are most abundant in beds having median grain-size values of -0.5 to $1.5 \phi$ (very coarse to medium sand). The difference corresponds to a difference in the size distribution of heavy minerals in the channel samples (fig. $5 B)$; that is, it is related to the nature of supply.

Gravelly bimodal samples have lower heavy-mineral contents than unimodal sand samples. Modal grain size of the heavy-mineral fractions appears to correspond to the sand-sized mode rather than to the gravel-sized mode of gravelly bimodal samples (fig. 4). This correspondence results because the supplied monomineralic heavy minerals are too fine and not sufficiently dense to correspond hydraulically to pebbles. Therefore, the gravel fraction merely dilutes the heavy-mineral content (fig. 6). Heavymineral concentrations in the sand fraction of gravelly samples from Kitt Brook average 7.5 percent, comparable to an average of 6.7 percent for unimodal Kitt Brook sands.

Sediment sorting appears to have limited influence on heavy-mineral content. The higher heavy-mineral contents in each section are in beds that have So values of 1.7 or lower (Folk-Ward 1.2 or lower). However, only bimodal gravelly foreset beds have So values higher than 1.7 , so most beds in the delta are sufficiently well sorted to have high heavy-mineral contents. The best sorted deposits (So 1.3) have heavy-mineral contents ranging from 3.5 percent, which is notably below the average at Kitt Brook, to 17.7 percent, which is above the average at Packerville. Plots of heavy-mineral content of Kitt Brook sands versus sorting coefficients show no trend. If gravels are included, the most poorly sorted deposits have low heavy-mineral contents, but this correlation is only the result of dilution by coarser material as discussed above. In a following section, sorting is further analyzed.

Heavy-mineral assemblage.-Differences in relative abundance of heavy-mineral species as a function of bed grain size are quite intricate and are comparable in total magnitude to the provenance effect on variation of mineral abundance between the two deltas. At Kitt Brook, the most obvious correspondence between mineralogy and grain size

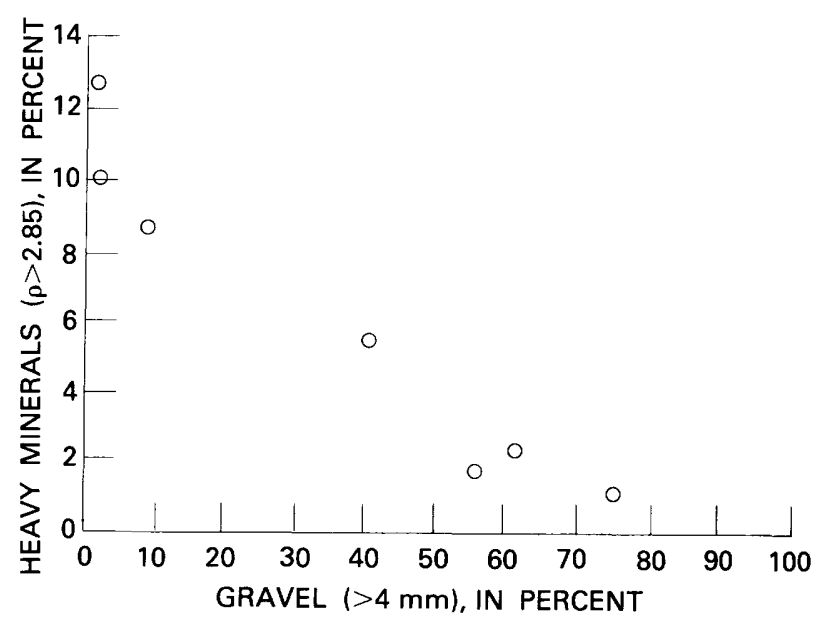

Figure 6. Heavy-mineral percentage versus gravel percentage at Kitt Brook; $\rho$, specific gravity.

is the degree of dominance by garnet, which is much greater in the coarser sands than in the finer sands (fig. 7A). The coarser Md of heavy-mineral-rich Kitt Brook sands (fig. $5 A$ ) is consistent with their dominance by coarse garnet. Apparently little fine-grained garnet was supplied to the Kitt Brook delta. The finer sands at Kitt Brook tend to concentrate heavy minerals of two types: (1) the minerals that are normally supplied as fine grains (such as rutile) and (2) the intermediate-density minerals biotite, sillimanite, tourmaline, and epidote (which here includes feldspar only partially replaced by epidote).

In the Packerville section, based on fewer data, minerals more abundant in finer sands are magnetite, ilmenite, epidote, sillimanite, rutile, and tourmaline (table 3 and fig. 7C). Only pale pyriboles are markedly more abundant in coarser sands. As at Kitt Brook, the finer sands contain either less dense minerals, such as epidote, or those likely to be supplied as fine grains.

\section{FACTORS CONTROLLING THE HEAVY MINERALOGY OF EACH BED}

The pervasive control of relative heavy-mineral abundance by bed texture is intriguing, and this study, with its well-constrained paleogeographic variables, allowed for effective isolation and testing of this effect. In this section we discuss the effect in terms of two variables, the nature of sediment supply to each delta and the nature of hydraulic sorting of each bed. The two variables interact in such a way that, given only the shape and density properties of each mineral, the entire heavy-mineral assemblage of each bed is determined. 


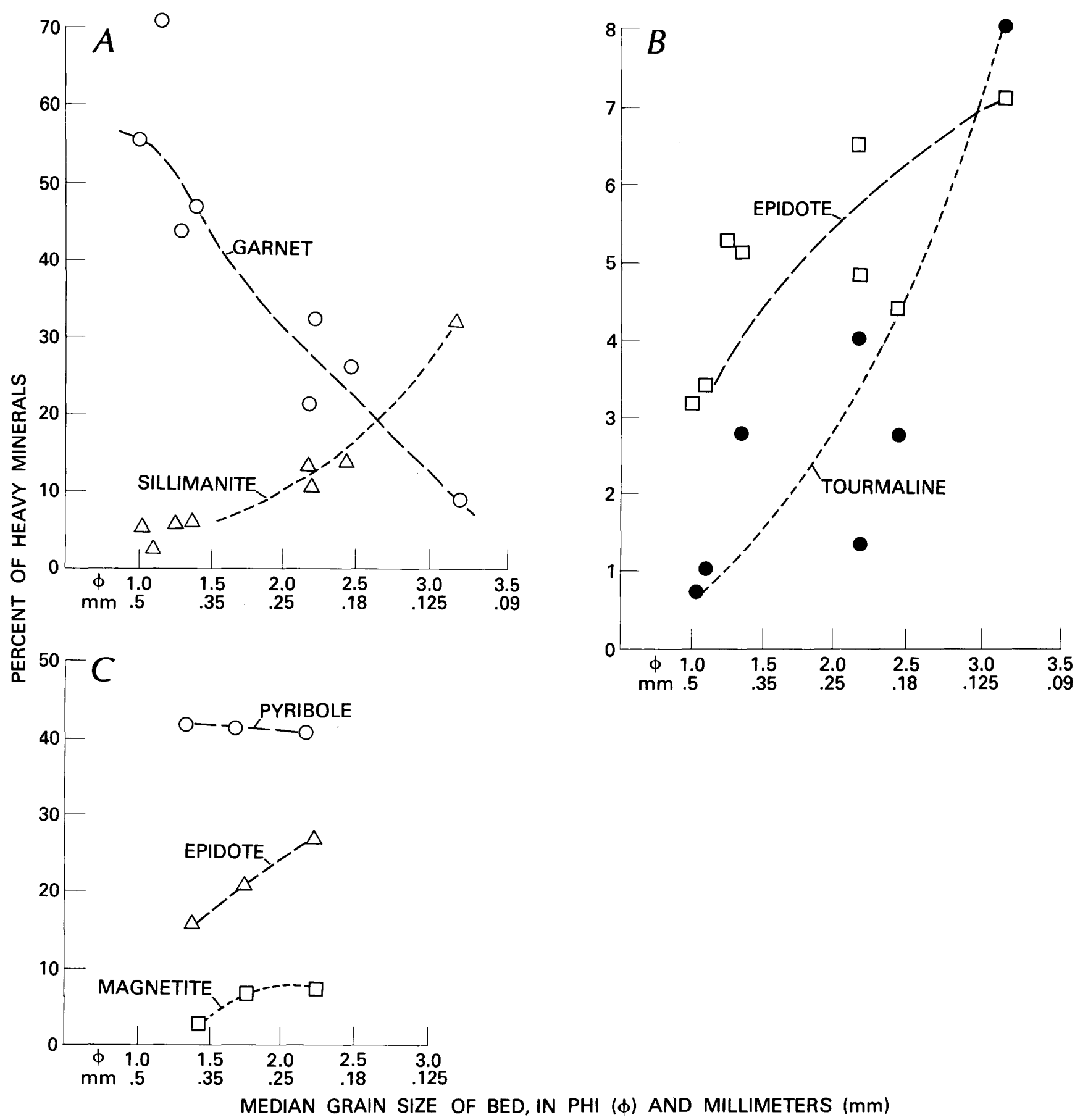

Figure 7. Variation of mineral abundance (as a percent of heavy concentrate) and median grain size. $A$, Kitt Brook delta, major constituents. $B$, Kitt Brook delta, minor constituents. $C$, Packerville delta.

\section{Grain-Size Distributions of Heavy Minerals Supplied to Each Delta}

The two deltas differ not only in relative and total abundance of heavy minerals but also in the grain-size distributions in which each mineral is supplied. The sizes in which each mineral is supplied to each delta are best shown by size distribution of the mineral in the channel sample of each delta (fig. 8), because the channel samples integrate foreset sediments and represent the sand-sized component of sediment supply to the delta. These size distributions in the channel samples are quite different for different miner- 
als within one delta and differ for the same mineral between deltas. The size distributions correspond closely (with a correction for mineral density, discussed below) to the variation of relative mineral abundance in beds of varying median grain sizes (fig. 7). That is, differences in relative availability of a mineral in different grain sizes are reflected in different abundances of that mineral in different beds. Thus a primary control of the mineralogy of a bed is the characteristic grain-size distribution of each mineral inherent in the nature of supply.

\section{Sorting by Shape and Density Within Each Bed}

Figure 4 shows the relation of total heavy-mineral size distributions to size distributions of whole samples in some typical foreset beds. Heavy-mineral distributions are normal and resemble those of the sand-sized portions of the whole samples but are typically shifted about $1 / 2 \phi$ toward a finer grain size. A shift of this magnitude and direction is expected where all the grains in the sample have similar settling velocities. That is, the grains are approximate hydraulic equivalents for deposition from suspension (in the sense of Rubey, 1933; Rittenhouse, 1943).

In more detail, each heavy-mineral species has a predictable grain-size distribution relative to the grain-size distribution of the whole sample. An array of size distributions for all the heavy minerals in a bed sample shows an intricate dependence on mineral density and shape. Such arrays were generated in this study in two ways. First, for those samples in which the $0.177-\mathrm{mm}(2.5 \phi)$ grain-size split for mineral identification was nearly coincident with the median grain size of a particular mineral, the measured difference between the median for that mineral and the median of the whole sample was determined (see table 4 and figure 9 for computed values). The values obtained from beds of all grain sizes and structures in both deltas are quite consistent, being sensitive only to the physical properties of the minerals. The behavior of biotite is unusual for heavy minerals; it tends to form grains coarser than the sand-sized median of the whole sample. Because biotite departs markedly from equant shape, the shape factor must have as much importance in its transport as does its density. More equant heavy-mineral species show median grain size about $0.5 \phi$ to more than $1 \phi$ finer than the sample mode, as a function of mineral density (fig. 9). The progression is similar to that documented by Rittenhouse (1943) for fluvial deposits.

A more detailed technique using only one sample was applied to the same problem. For sample K12, a heavymineral-rich sand with subsidiary coarse mode, minerals were identified in four size fractions, and a grain-size distribution of each mineral was determined (fig. 10). The results are generally similar to these obtained from all
Table 4. Average arithmetic difference between median grain sizes of whole samples and of individual constituent minerals, Kitt Brook and Packerville deltas

\begin{tabular}{|c|c|c|c|}
\hline \multirow[t]{2}{*}{ Mineral } & \multicolumn{2}{|c|}{$\begin{array}{c}\text { Average } \\
\phi \text { separation } \\
\text { toward fines }\end{array}$} & \multirow[t]{2}{*}{$\begin{array}{l}\text { Number of } \\
\text { observations }\end{array}$} \\
\hline & All samples & $\mathrm{K} 12$ & \\
\hline Magnetite ......... & $1.05 \ldots \ldots$ & $1.05 \ldots \ldots \ldots$ & 3 \\
\hline Ilmenite . . . . . . . & $1.00 \ldots \ldots$ & $.95 \ldots \ldots \ldots$ & 3 \\
\hline Garnet..$\ldots \ldots \ldots$ & $.74 \ldots \ldots$ & $.5 \ldots \ldots \ldots$ & 7 \\
\hline Dark pyribole...... & $.76 \ldots \ldots$ & 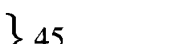 & 6 \\
\hline Light pyribole ..... & $.71 \ldots \ldots$ & & 7 \\
\hline Biotite..$\ldots \ldots \ldots$ & $>.5$ coarser & .45 coarser. & 2 \\
\hline Epidote...$\ldots \ldots$ & $.65 \ldots \ldots$ & $.55 \ldots \ldots \ldots$ & 5 \\
\hline Staurolite......... & $.73 \ldots \ldots$ & $.45 \ldots \ldots \ldots$ & 6 \\
\hline Sillimanite ....... & $.48 \ldots \ldots$ & $.50 \ldots \ldots \ldots$ & 5 \\
\hline Kyanite ........... & $.60 \ldots \ldots$ & $.20 \ldots \ldots \ldots$ & 4 \\
\hline Zircon ............ & $1.00 \ldots \ldots$ & $.80 \ldots \ldots$ & 2 \\
\hline Tourmaline........ & $.58 \ldots \ldots$ & $.65 \ldots \ldots \ldots$ & 5 \\
\hline
\end{tabular}

samples (table 4), and the array again is a function of mineral density and shape (note kyanite in fig. 9).

Figures 9 and 10 strongly suggest that deposition of heavy minerals in the foreset beds occurred in conditions of suspension equivalence (that is, that grains of the same settling velocity occur together). This suspension equivalence in turn is consistent with our bulk compositional data that show no enrichments of heavy minerals in foresets compared to source rocks. Enrichment generally involves more complex types of hydraulic equivalence (Rittenhouse, 1943; Force, 1976; Komar and Wang, 1984; Slingerland and Smith, 1986).

Implications regarding sorting studies. -Figure 10 shows that sample K12, although moderately well sorted (So 1.5 , Folk-Ward 0.80 ), actually contains a mixture of mineralogic size populations, each of which is much better sorted (So 1.2-1.3, Folk-Ward 0.28-0.52) than the whole bed. The heavy minerals together form a heavy-mineral fraction having So 1.3 (Folk-Ward 0.52). Thus this sample is a mixed population both texturally (admixed coarse mode) and mineralogically (heavy minerals), and both factors contribute to lesser sorting for the whole sample.

Where grains of the same shape and density are measured, the sorting of glacial lake delta sands can be exquisite. The size distribution of the whole sample is only a weighted average of a series of tighter distributions of individual minerals. Among unimodal samples, polymineralic sands that have minerals differing in density and shape are necessarily more poorly sorted than monomineralic sands deposited under similar conditions. Although this effect is probably minor in most polymineralic sands, it works contrary to the purpose of sorting investigations. We suggest that, in studies of mineralogically immature sands, 


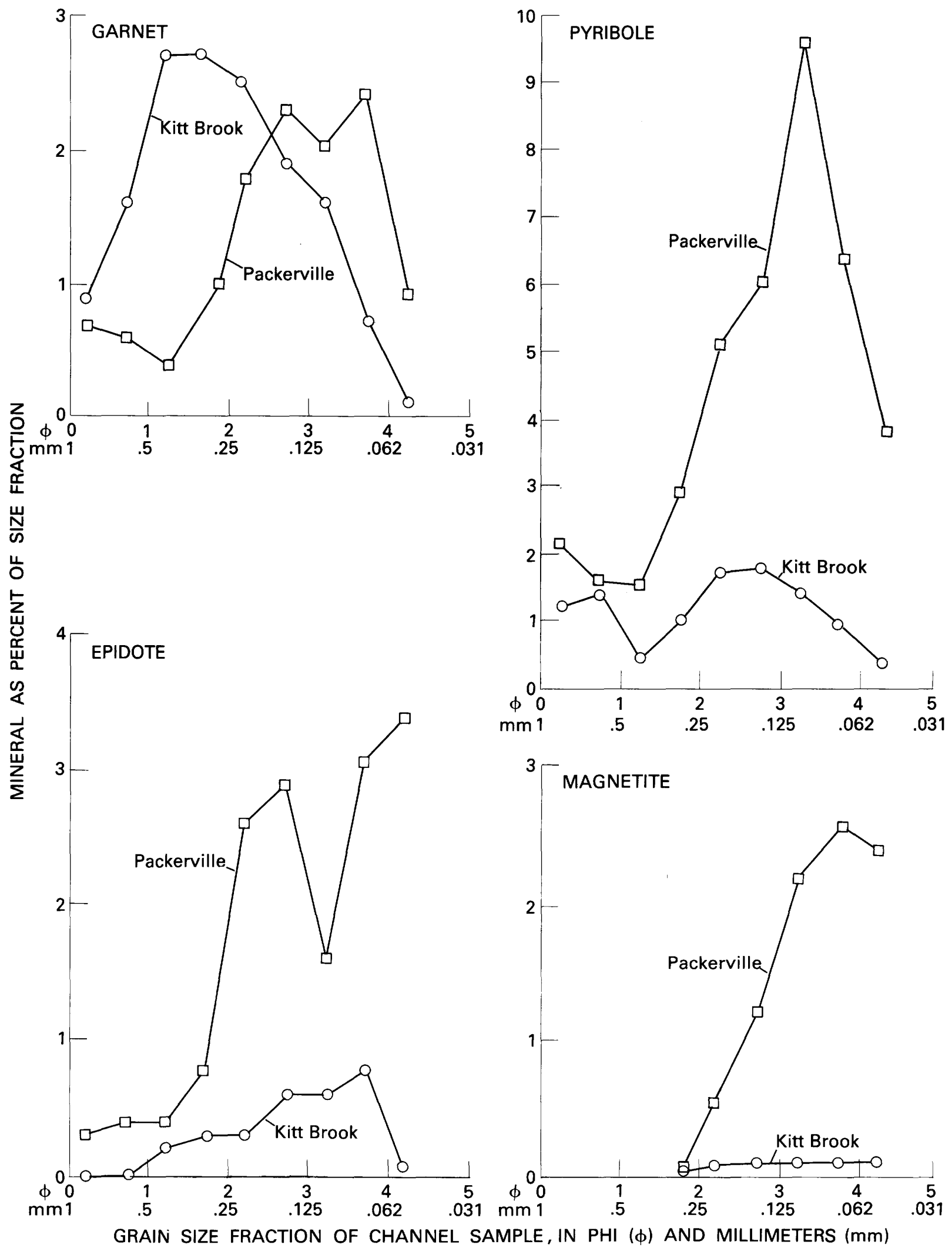

Figure 8. Concentration of heavy-mineral species in grain-size fractions of channel samples of exposed foreset sequences in the Kitt Brook and Packerville deltas. Mineral abundance is shown as a percentage of each grain-size class. 


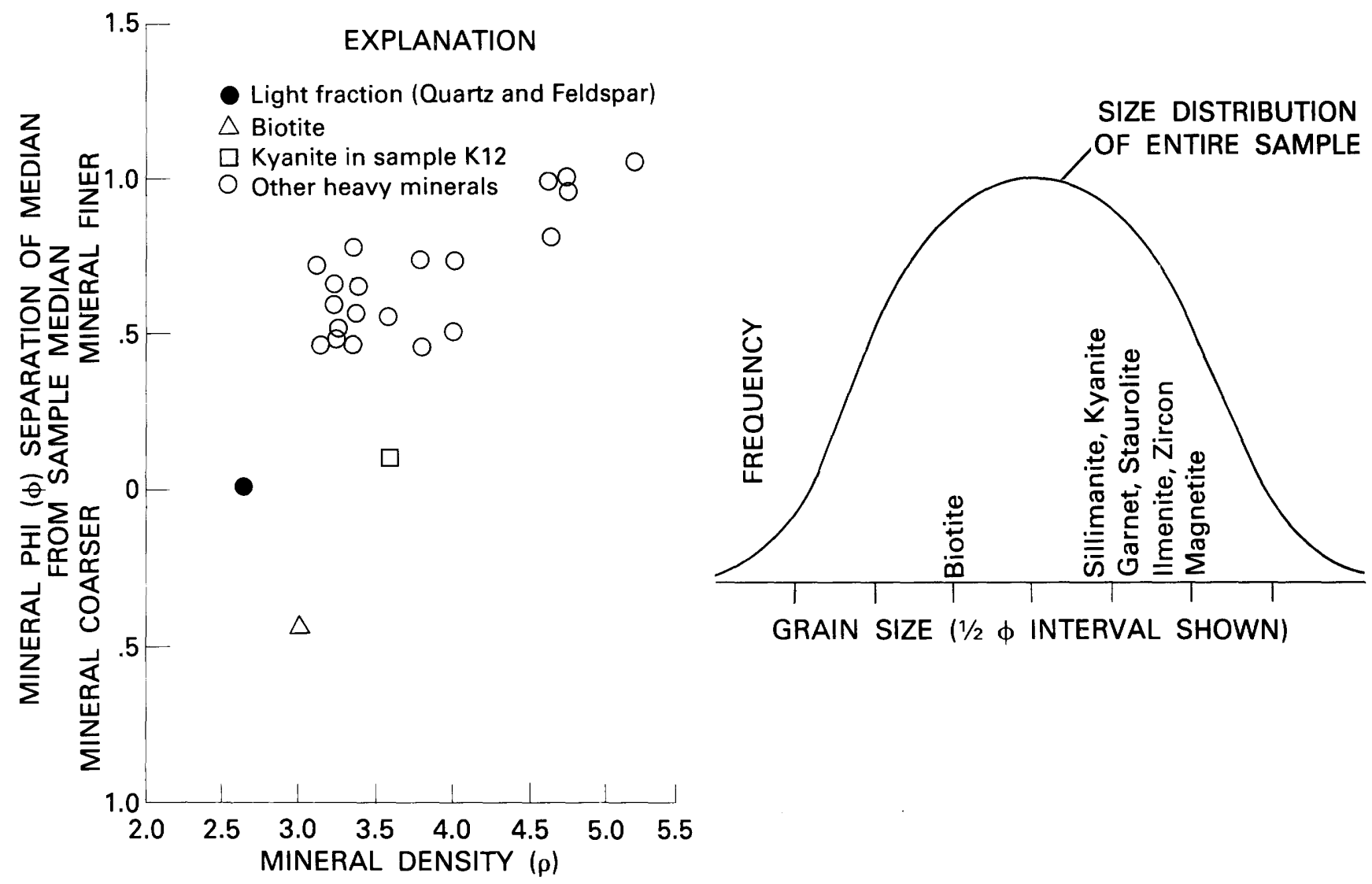

Figure 9. Mineral density versus the difference between median mineral grain size and median sample grain size, derived from all samples from the Kitt Brook and Packerville deltas. Inset (right) shows idealized relation to frequency diagram of a whole sample.

sorting of minerals of similar density be measured to avoid confusing textural and mineralogic immaturity.

Implications regarding heavy-mineral study techniques. - The common technique of comparing the heavy mineralogies of only one standard size interval among samples would have had inadequate or misleading results if employed for these sands (and for others, as first noted by Rubey, 1933). Any given size interval falls in differing relation to the grain-size distributions of various samples and thus enriches different parts of the density-shape spectrum of mineral species. Two samples having identical bulk mineral assemblages but different grain-size distributions will yield different mineral assemblages if only one size fraction is examined. We emphasize that this common technique is misleading except where (1) sediment is unsorted, (2) all samples have the same sand-sized mode, or (3) relative abundance only of minerals of the same density is considered.

\section{Factor Interrelation and Consequent Predictive Capacity}

In the study area, each source terrane and its icemarginal drainage system contributed debris that had a characteristic proportion of minerals. Grains of each mineral were supplied in a characteristic size distribution. The supply distributions for Kitt Brook are shown in figure 11A, which was generated from information found in figures 7 and 8 . Each bed (or lamina) draws grains from the population supplied.

As a result of hydraulic factors, each bed (or lamina) has a certain grain-size distribution for light minerals and a family of related heavy-mineral distributions (fig. 11B). A particular heavy mineral is concentrated where the size of the mineral that can be deposited by the flow (fig. 11B) corresponds with a size supplied in abundance (fig. 11A). For the fine-sand sample shown in figure $11 B$ (solid curves), very fine-grained ilmenite and medium-grained 

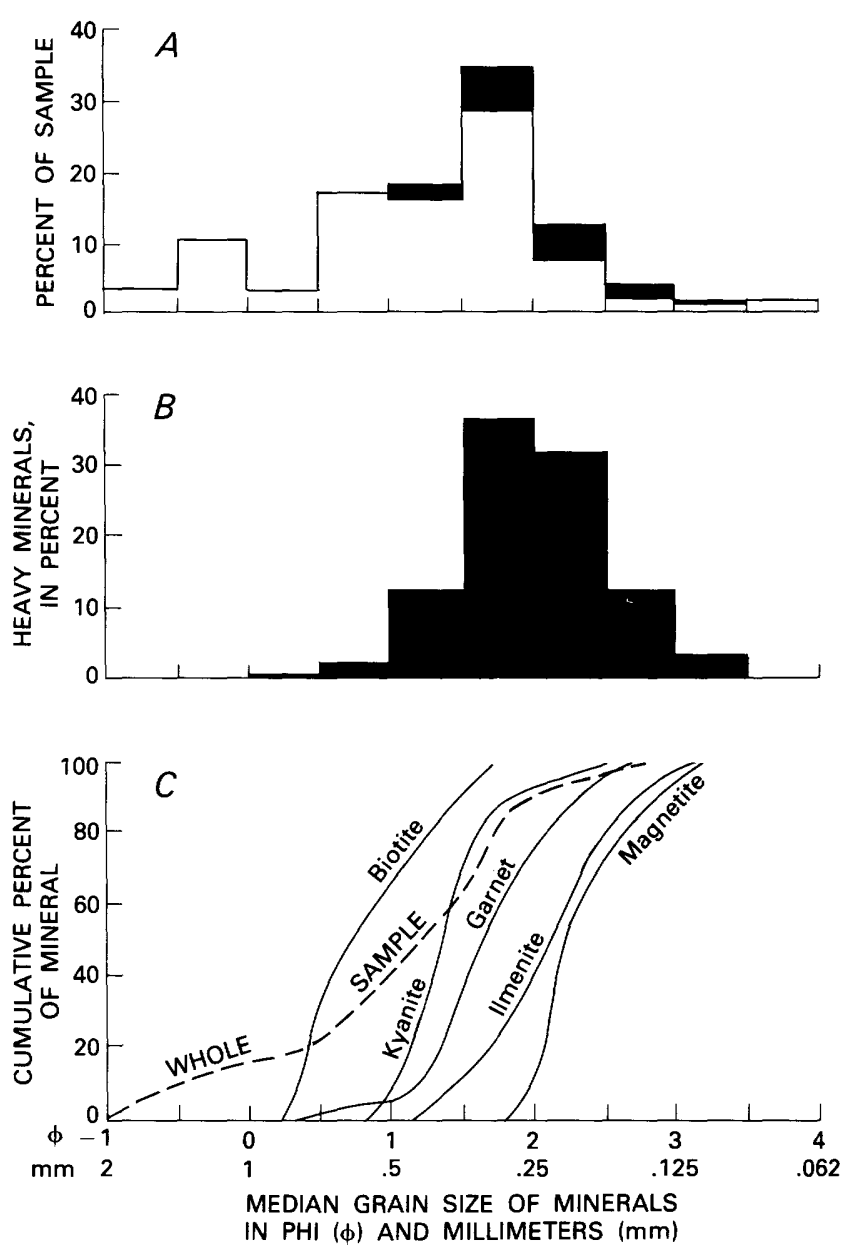

Figure 10. Grain-size distribution histograms for sample K12 of, $A$, Whole sample, $B$, Heavy minerals, and, $C$, Cumulative curves for whole sample and several mineral species. Dark pattern denotes heavy minerals.

biotite are concentrated. For a coarser sample, the whole grain-size distribution, including all the component heavymineral curves, would be shifted to the left so that different components of mineral supply would be tapped. In a sample having Md $-0.5 \phi$ (dashed, fig. $11 B$ ), coarse garnet would be concentrated instead of biotite and ilmenite. Where the nature of the supply is different, as it is at Packerville, the minerals concentrated at each median grain size would also be different.

Given the grain-size distribution of any sample and the size distributions of mineral supply in its delta, we should be able to predict abundance and grain-size information for each heavy-mineral species. The modal grain size of a given heavy-mineral species is calculated relative to the sand-sized mode of the whole sample, by use of figures 9 and 10 and table 4 . The abundance of this mineral in this sample is proportional to the height of the supply distribution of the mineral at its modal grain size. Our prediction method embodies the hydraulic ratio concept of Rittenhouse (1943) but, in our opinion, is easier to use.

\section{MODE OF HEAVY-MINERAL DEPOSITION}

The grain-size relation of heavy-mineral species to light minerals and to other heavy minerals in the foreset beds of the two deltas strongly suggests that deposition from suspension was an important process, as the grains have similar settling velocities. There is no evidence in the grain-size distributions for enrichment by reentrainment, as described by Slingerland and Smith (1986), for this process selects more by grain size than by density and produces less size separation among the array of mineral populations than we observed. The little heavy-mineral enrichment that we observed in some beds is explained by the interrelation of bed texture and the size distribution of mineral supply.

Observations from sedimentary structures are consistent with an important suspension component of deposition and suggest that this component varied from bed to bed. In those beds or intervals showing type-B climbing ripples, traction transport must be minor, and deposition was largely from suspension (Jopling and Walker, 1968; Ashley and others, 1982). Type-A ripples show that traction transport was more important, that reentrainment occurred, but that accumulation from suspension was still important. Some foreset beds having moderate dip show transitions from planar to very low-angle type-A rippled beds; these beds have still higher components of traction transport. In all beds regardless of structure, however, suspension equivalence is suggested by the grain-size distributions of constituent minerals. Sample K12, from a planar bed just above a disconformity, is our best studied example of suspension equivalence.

The sandy foreset beds are rather well sorted. Minerals of equal density are locally very well sorted (even in the terminology of Folk and Ward, 1957). The depositional mechanism must explain not only suspension equivalence but also this locally excellent sorting.

We envision deposition from continuous but nonsteady turbidity currents moving down foreset slopes as turbid suspensions denser than lake water. On upper foreset slopes of $10^{\circ}$ to $30^{\circ}$ where deposition is occurring, there is little evidence of either deceleration or acceleration of flow at a scale of individual outcrops. Only grains having a certain minimum settling velocity can settle out from such a suspension. In poorly sorted coarse beds, all such grains are deposited with bedload. However, most sand beds show a narrow spectrum of settling velocities. Finer grains were deposited elsewhere. The role of traction transport varied from bed to bed. 

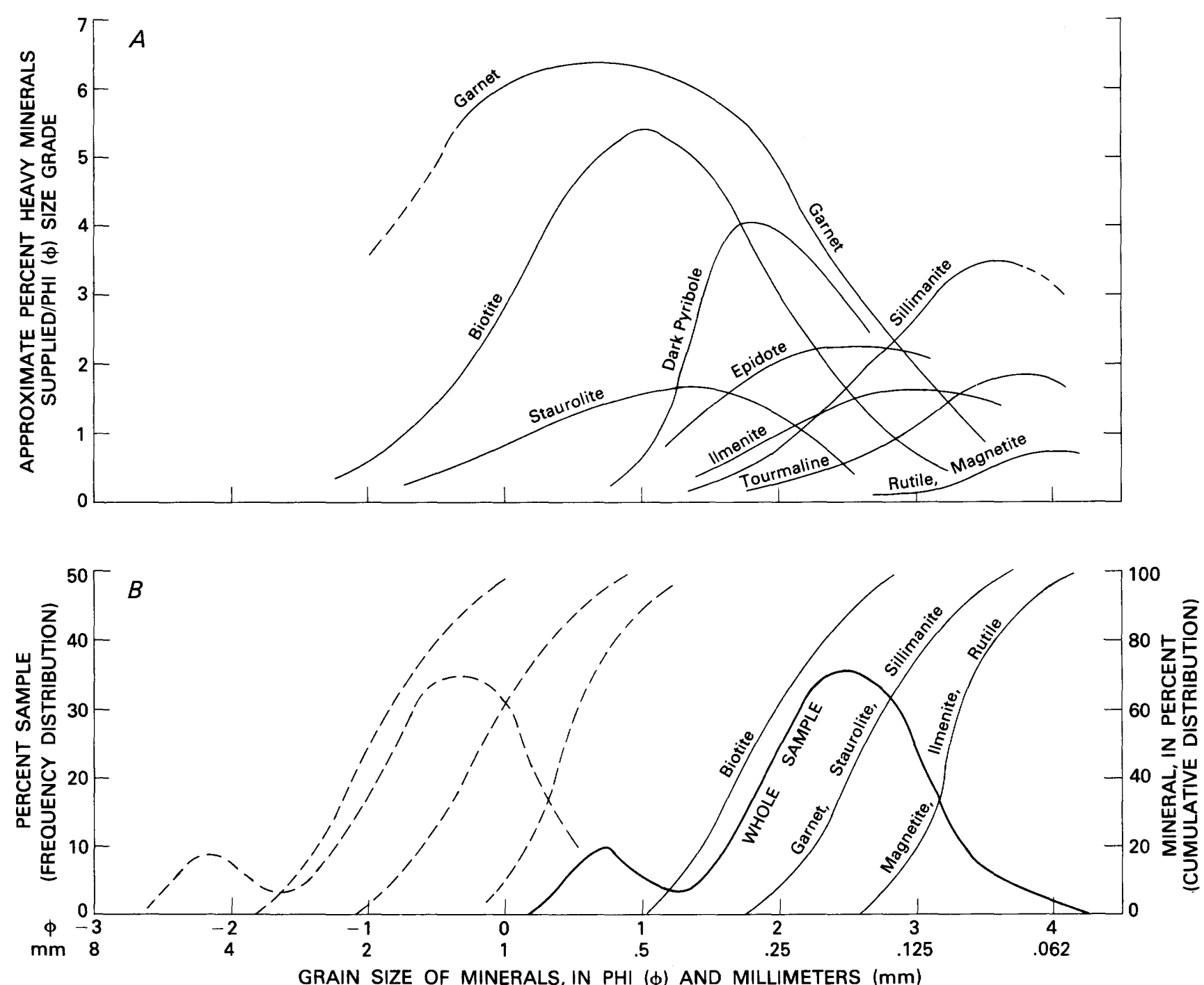

Figure 11. Relation of size distributions of supplied debris and of any given sample and its contained minerals. $A$, The graph for supplied debris is a function of, and varies with, the source terrane and erosion agents. The distribution shown is for the Tatnic Hill terrane and is calculated from the varying mineralogies of beds of differing grain sizes in the Kitt Brook delta (see fig. 7) and from its channel sample (fig. 8). Each mineral is supplied in the range of size intervals shown. $B$, The size distribu-

\section{ICE-MARGINAL SUPPLY AND DISPERSAL SYSTEM}

The contrast in mineral assemblages of the two deltas provides constraints on reconstructed dispersal patterns of the glacial sediment in the study area. The characteristic mineral abundance of each delta is directly related to that of the immediately adjacent bedrock source terrane. Distinct mineral assemblages and mineral size distributions in each delta imply very little mixing of sediment across the bedrock terrane boundary. Further, the mineral suites of till tion of a sample varies from bed to bed or part thereof. A fine sand with its constituent heavy minerals is shown in solid lines; this size distribution should be considered mobile in its entirety from right to left to represent samples of coarser grain size (dashed). Enrichments of particular heavy minerals occur where the cumulative curve for that mineral in the sample $(B)$ can be made to match an interval of abundant supply $(A)$.

samples from the two source terranes (table 2) are closely related to the mineralogy of the two deltaic deposits. Accordingly, the transport scheme must be as diagramed in figure 12. During deglaciation, glacial transport of till was only slightly oblique to the terrane boundary, and little debris was dispersed across that boundary. For some minerals, for example, magnetite and garnet in euhedral grains, grain size in the deltas represents original grain size in source rocks.

Along the stagnant ice margin, meltwater carrying locally derived glacial debris converged on Lake Quine- 


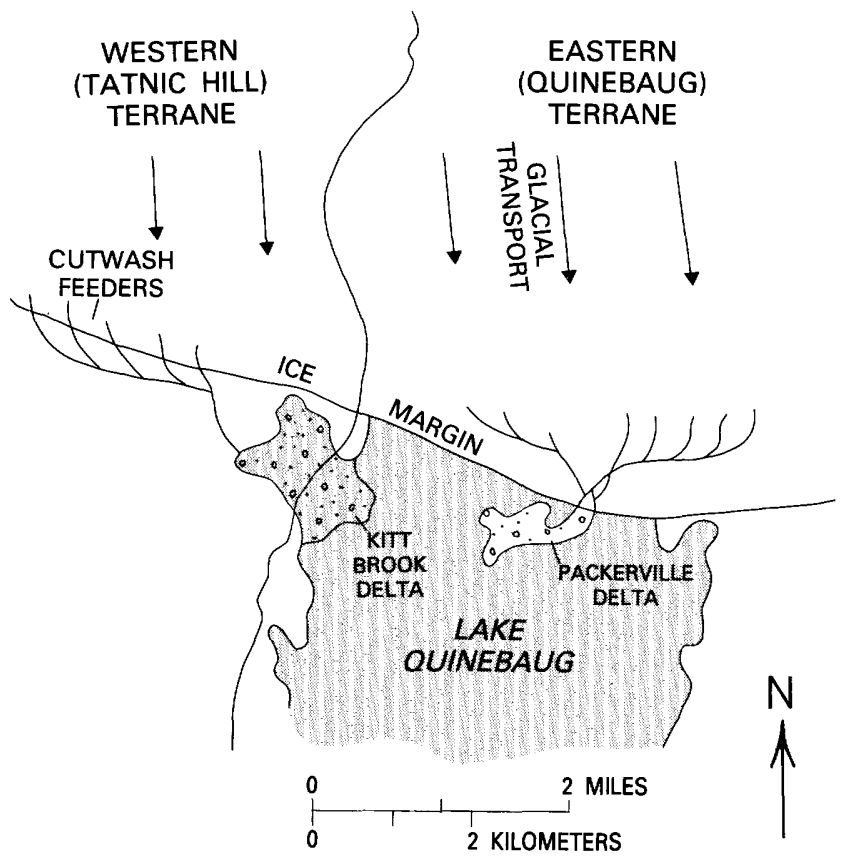

Figure 12. Ice-marginal supply and dispersal directions in the study area.

baug. Sand- and gravel-sized sediment was entrained in meltwater streams and carried across the delta braidedstream topset plain where most gravel remained. Meltwater flow continued into the lakes as nonsteady continuous underflows on the delta foreset slopes; the hydraulic parameters of these flows determined the grain size of each foreset bed, and with the size distribution of mineral supply, determined its mineralogy.

\section{ACKNOWLEDGMENTS}

We thank Kimberley Winkler for performing many mineral separations and Katharine Schindler, John Peper, Harry Tourtelot, Norman Smith, and Curt Larsen for editing and reviewing the manuscript. Jane Dodge rescued the samples from a Connecticut railroad platform.

\section{REFERENCES}

Aario, Risto, 1971, Associations of bed forms and paleocurrent patterns in an esker delta, Haapajarvi, Finland: Annales Academiae Scientiarum Fennicae, ser. A., pt. 3, no. 111, 55 p.

Allen, J.R.L., 1971, A theoretical and experimental study of climbing-ripple cross-lamination, with a field application to the Uppsala esker: Geografiska Annaler, v. 53A, p. 157-187.

Ashley, G.M., Southard, J.B., and Boothroyd, J.C., 1982, Deposition of climbing-ripple beds: A flume simulation: Sedimentology, v. 29 , no. 1 , p. 67-69.
Cohen, J.M., 1979, Deltaic sedimentation in glacial Lake Blessington, County Wicklow, Ireland, in Schlüchter, Christian, ed., Moraines and varves: Rotterdam, A.A. Balkema, p. 357-367.

1983, Subaquatic mass flows in a high energy ice marginal deltaic environment and problems with the identification of flow tills, in Evenson, E.B., and others, eds., Tills and related deposits: Rotterdam, A.A. Balkema, p. 255-267.

Davis, W.M., 1980, Structure and origin of glacial sandplains: Geological Society of America Bulletin, v. 1, p. 195-202.

Dixon, H.R., 1964, The Putnam Group of eastern Connecticut: U.S. Geological Survey Bulletin 1194-C, 12 p.

1965, Bedrock geologic map of the Plainfield quadrangle, Windham and New London Counties, Connecticut: U.S. Geological Survey Geologic Quadrangle Map GQ-481, scale $1: 24,000$.

Dixon, H.R., and Shaw, C.E., Jr., 1965, Geologic map of the Scotland quadrangle, Connecticut: U.S. Geological Survey Geologic Quadrangle Map GQ-392, scale 1:24,000.

Dreimanis, Alexis, and Vagners, V.J., 1969, Bimodal distribution of rock and mineral fragments in basal tills, in Goldthwait, R.P., ed., Till, a symposium: Columbus, Ohio, Ohio State University Press, p. 237-250.

Folk, R.L., and Ward, W.C., 1957, Brazos River bar: A study in the significance of grain size parameters: Journal of Sedimentary Petrology, v. 27, p. 3-26.

Force, E.R., 1976, Metamorphic source rocks of titanium placer deposits: U.S. Geological Survey Professional Paper 959-B, $16 \mathrm{p}$.

Force, E.R., Lipin, B.R., and Smith, R.E., 1976, Heavy mineral resources in Pleistocene sand of the Port Leyden quadrangle, southwestern Adirondack Mountains, New York: U.S. Geological Survey Miscellaneous Field Studies Map MF-728-B, scale $1: 24,000$.

Gilbert, G.K., 1885, The topographic features of lake shores: Fifth Annual Report, U.S. Geological Survey, p. 69-123.

Goldsmith, Richard, and Force, E.R., 1978, Distribution of rutile in metamorphic rocks and implications for placer deposits: Mineralium Deposita, v. 13, p. 329-343.

Goldsmith, Richard, Zietz, Isidore, and Dixon, H.R., 1977, Correlation of aeroradioactivity and geology in southeastern Connecticut and adjacent New York and Rhode Island: Geological Society of America Bulletin, v. 88, p. 925-934.

Gustavson, T.C., 1975, Sedimentation and physical limnology in proglacial Malaspina Lake, Southeastern Alaska, in Jopling, A.V., and McDonald, B.C., eds., Glaciofluvial and glaciolacustrine sedimentation: Society of Economic Paleontologists and Mineralogists Special Publication 23, p. 249-263.

Gustavson, T.C., Ashley, G.M., and Boothroyd, J.C., 1975, Depositional sequences in glaciolacustrine deltas, in Jopling, A.V., and McDonald, B.C., eds., Glaciofluvial and glaciolacustrine sedimentation: Society of Economic Paleontologists and Mineralogists Special Publication 23, p. 264-280.

Jopling, A.V., and Walker, R.G., 1968, Morphology and origin of ripple-drift cross-lamination with examples from the Pleistocene of Massachusetts: Journal of Sedimentary Petrology, v. 38 , p. 971-984.

Komar, P.D., and Wang, Chi, 1984, Processes of selective grain transport and the formation of placers on beaches: Journal of Geology, v. 92, no. 6, p. 637-655. 
Koteff, Carl, and Pessl, Fred, Jr., 1981, Systematic ice retreat in New England: U.S. Geological Survey Professional Paper $1179,20 \mathrm{p}$.

Krynine, P.D., 1937, Glacial sedimentology of the QuinnipiacPequabuck lowland in southern Connecticut: American Journal of Science, v. 33, no. 194, p. 111-139.

Rittenhouse, Gordon, 1943, Transportation and deposition of heavy minerals: Geological Society of America Bulletin, v. 54 , p. $1725-1780$.

Rubey, W.W., 1933, The size distribution of heavy minerals within a water-laid sandstone: Journal of Sedimentary Petrology, v. 3, p. 3-29.

Schafer, J.P., and Hartshorn, J.H., 1965. The Quaternary of New England, in Wright, H.E., Jr., and Frey, D.G., eds., The Quaternary of the United States: Princeton, New Jersey, Princeton University Press, p. 113-127.

Serrat, David, Vilaplana, J.M., and Marti, C.E., 1983, Some depositional models in glaciolacustrine environments (southern Pyrenees), in Evenson, E.B., and others, eds., Tills and related deposits: Rotterdam, A.A. Balkema, p. 231-244.

Shaw, John, 1975, Sedimentary successions in Pleistocene icemarginal lakes, in Jopling, A.V., and McDonald, B.C., eds., Glaciofluvial and glaciolacustrine sedimentation: Society of Economic Paleontologists and Mineralogists Special Publication 23, p. 281-303.

Slingerland, Rudy, and Smith, N.D., 1986, Occurrence and formation of waterlaid placers: Annual Review of Earth and Planetary Sciences, v. 14, p. 113-147.

Smith, N.D., and Ashley, Gail, 1985, Proglacial lacustrine environment, in Ashley, G.M., Shaw, John, and Smith, N.D., eds., Glacial sedimentary environments: Society of Economic Paleontologists and Mineralogists Short Course 16, p. 135-216.

Stewart, D.P., and MacClintock, Paul, 1970, The surficial geologic map of Vermont (Doll, C.G., ed.): Vermont Geological Survey, scale 1:250,000.
Stone, B.D., 1974, The Quaternary geology of the Plainfield and Jewett City quadrangles, central eastern Connecticut: Baltimore, Maryland, The Johns Hopkins University, Ph.D. dissertation, $217 \mathrm{p}$.

1978, Surficial geologic map of the Jewett City quadrangle, New London County, Connecticut: U.S. Geological Survey Geologic Quadrangle Map GQ-1434, scale 1:24,000.

Stone, B.D., and Borns, H.W., Jr., 1986, Pleistocene glacial and interglacial stratigraphy of New England, Long Island, and adjacent Georges Bank and Gulf of Maine, in Sibrava, Vladimir, Bowen, D.Q., and Richmond, G.M., eds., Quaternary glaciations of the northern hemisphere: Quaternary Science Reviews, v. 5, p. 39-52.

Stone, B.D., and Force, E.R., 1980, The Port Leyden, New York, heavy mineral deposit: New York State Museum Bulletin 436, p. 57-64.

1982, Sedimentary sequences and petrology of glaciolacustrine deltas, eastern Connecticut, U.S.A.: 11th International Congress on Sedimentology, Hamilton, Ontario, Aug. 1982, Abstracts, p. 24.

1983, Coarse-grained glaciolacustrine deltaic sedimentation in ice-marginal and ice-channel environments: Geological Society of America Abstracts with Programs, v. 14, no. 7, p. 759.

Stone, B.D., and Peper, J.D., 1982, Topographic control of the deglaciation of eastern Massachusetts: Ice lobation and the marine incursion, in Larson, G.J., and Stone, B.D., eds., Late Wisconsin glaciation of New England: Dubuque, Iowa, Kendall/Hunt Publishing Co., p. 145-166.

Stone, B.D., and Randall, A.D., 1978, Surficial geologic map of the Plainfield quadrangle, Windham and New London Counties, Connecticut: U.S. Geological Survey Geologic Quadrangle Map GQ-1422, scale 1:24,000.

Trask, P.D., 1932, Origin and environment of source sediments of petroleum: Houston, Texas, Gulf Publishing Co., 323 p. 





\section{Perlodicals}

Earthquakes \& Volcanoes (issued bimonthly).

Preliminary Determination of Epicenters (issued monthly).

\section{Technical Books and Reports}

Professional Papers are mainly comprehensive scientific reports of wide and lasting interest and importance to professional scientists and engineers. Included are reports on the results of resource studies and of topographic, hydrologic, and geologic investigations. They also include collections of related papers addressing different aspects of a single scientific topic.

Bulletins contain significant data and interpretations that are of lasting scientific interest but are generally more limited in scope or geographic coverage than Professional Papers. They include the results of resource studies and of geologic and topographic investigations; as well as collections of short papers related to a specific topic.

Water-Supply Papers are comprehensive reports that present significant interpretive results of hydrologic investigations of wide interest to professional geologists, hydrologists, and engineers. The series covers investigations in all phases of hydrology, including hydrogeology, availability of water, quality of water, and use of water.

Circulars present administrative information or important scientific information of wide popular interest in a format designed for distribution at no cost to the public. Information is usually of short-term interest.

Water-Resources Investigations Reports are papers of an interpretive nature made available to the public outside the formal USGS publications series. Copies are reprociuced on request unlike formal USGS publications, and they are also available for public inspection at depositories indicated in USGS catalogs.

Open-File Reports include unpublished manuscript reports, maps, and other material that are made available for public consultation at depositories. They are a nonpermanent form of publication that may be cited in other publications as sources of information.

\section{Maps}

Geologic Quadrangle Maps are multicolor geologic maps on topographic bases in 71/2-or 15-minute quadrangle formats (scales mainly $1: 24,000$ or $1: 62,500$ ) showing bedrock, surficial, or engineering geology. Maps generally include brief texts; some maps include structure and columnar sections only.

Geophysical Investigations Maps are on topographic or planimetric bases at various scales; they show results of surveys using geophysical techniques, such as gravity, magnetic, seismic, or radioactivity, which reflect subsurface structures that are of economic or geologic significance. Many maps include correlations with the geology.

Miscellaneous Investigations Series Maps are on planimetric or topographic bases of regular and irregular areas at various scales; they present a wide variety of format and subject matter. The series also includes $71 / 2$-minute quadrangle photogeologic maps on planimetric bases which show geology as interpreted from aerial photographs. Series also includes maps of Mars and the Moon.
Coal Investigations Maps are geologic maps on topographic or planimetric bases at various scales showing bedrock or surficial geology, stratigraphy, and structural relations in certain coal-resource areas.

Oll and Gas Investigations Charts show stratigraphic information for certain oil and gas fields and other areas having petroleum potential.

Miscellaneous Field Studies Maps are multicolor or black-andwhite maps on topographic or planimetric bases on quadrangle or irregular areas at various scales. Pre-1971 maps show bedrock geology in relation to specific mining or mineral-deposit problems; post-1971 maps are primarily black-and-white maps on various subjects such as environmental studies or wilderness mineral investigations.

Hydrologic Investigations A tlases are multicolored or black-andwhite maps on topographic or planimetric bases presenting a wide range of geohydrologic data of both regular and irregular areas; principal scale is $1: 24,000$ and regional studies are at $1: 250,000$ scale or smaller.

\section{Catalogs}

Permanent catalogs, as well as some others, giving comprehensive listings of U.S. Geological Survey publications are available under the conditions indicated below from the U.S. Geological Survey, Books and Open-File Reports Section, Federal Center, Box 25425, Denver. CO 80225. (See latest Price and Availability List)

"Publications of the Geological Survey, 1879- 1961" may be purchased by mail and over the counter in paperback book form and as a set of microfiche.

"Publications of the Geological Survey, 1962- 1070" may be purchased by mail and over the counter in paperback book form and as a set of microfiche.

"Publications of the U.S. Geological Survey, 1971-1981" may be purchased by mail and over the counter in paperback book form (two volumes, publications listing and index) and as a set of microfiche.

Supplements for 1982, 1983, 1984, 1985, 1986, and for subsequent years since the last permanent catalog may be purchased by mail and over the counter in paperback book form.

State catalogs, "List of U.S. Geological Survey Geologic and Water-Supply Reports and Maps For (State)," may be purchased by mail and over the counter in paperback booklet form only.

"Price and Availability List of U.S. Geological Survey Publications," issued annually, is available free of charge in paperback booklet form only.

Selected copies of a monthly catalog "New Publications of the U.S. Geological Survey" available free of charge by mail or may be obtained over the counter in paperback booklet form only. Those wishing a free subscription to the monthly catalog "New Publications of the U.S. Geological Survey" should write to the U.S. Geological Survey, 582 National Center, Reston, VA 22092.

Note.--Prices of Government publications listed in older catalogs, announcements, and publications may be incorrect. Therefore, the prices charged may differ from the prices in catalogs, announcements, and publications. 


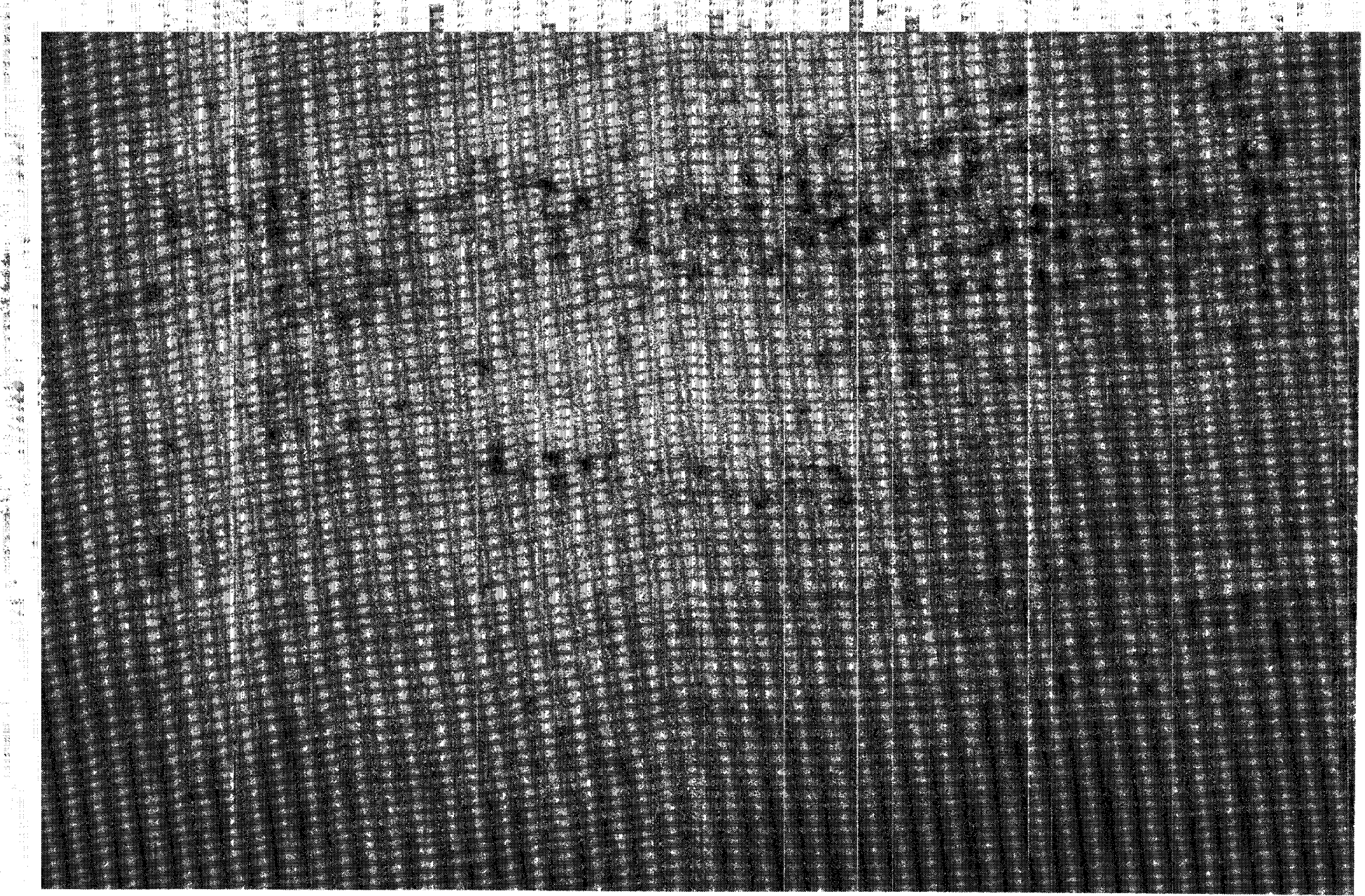

